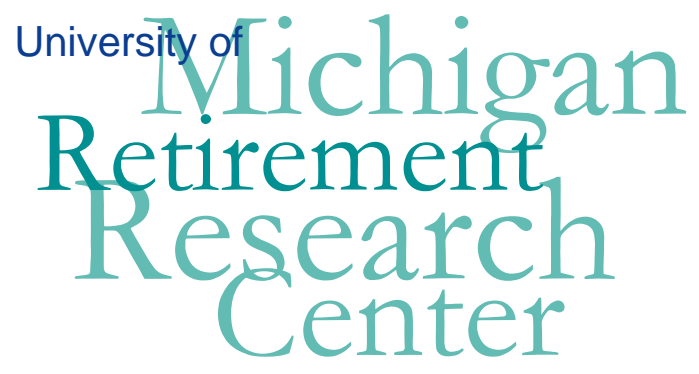

Working Paper

WP 2008-181

\title{
Immigrant-Native Fertility and Mortality Differentials in the United States
}

Purvi Sevak and Lucie Schmidt

\begin{tabular}{|c|c|l|}
\hline $\mathrm{M}$ & $\mathrm{R}$ & Project \#: UM08-02 \\
\cline { 1 - 2 } & $\mathrm{C}$ & http://ssrn.com/abstract=1287297
\end{tabular} 


\title{
Immigrant-Native Fertility and Mortality Differentials in the United States
}

\author{
Pervi Sevak \\ Hunter College \\ Lucie Schmidt \\ Williams College
}

September 2008

\author{
Michigan Retirement Research Center \\ University of Michigan \\ P.O. Box 1248 \\ Ann Arbor, MI 48104 \\ http://www.mrrc.isr.umich.edu/
}

(734) 615-0422

\section{Acknowledgements}

This work was supported by a grant from the Social Security Administration through the Michigan Retirement Research Center (Grant \# 10-P-98362-5-04). The findings and conclusions expressed are solely those of the author and do not represent the views of the Social Security Administration, any agency of the Federal government, or the Michigan Retirement Research Center.

\section{Regents of the University of Michigan}

Julia Donovan Darrow, Ann Arbor; Laurence B. Deitch, Bingham Farms; Olivia P. Maynard, Goodrich; Rebecca McGowan, Ann Arbor; Andrea Fischer Newman, Ann Arbor; Andrew C. Richner, Grosse Pointe Park; S. Martin Taylor, Gross Pointe Farms; Katherine E. White, Ann Arbor; Mary Sue Coleman, ex officio 


\title{
Immigrant-Native Fertility and Mortality Differentials in the United States
}

\author{
Purvi Sevak and Lucie Schmidt
}

\begin{abstract}
Immigrants have been discussed as a means of alleviating fiscal pressures on Social Security. Their long-term impact on the Social Security system depends critically on their fertility and mortality patterns. In this paper, we examine the fertility and mortality patterns of immigrants to the United States and compare these patterns with those of non-immigrants. We find that both the recent and cumulative fertility of immigrant women is higher than that of native-born women, but that a large share of these differentials can be "explained" by differences in age structures, race and ethnicity, years in the United States, and country of origin. Using a synthetic cohort approach, we examine the role of years in the United States in more detail, and find no evidence of assimilation towards native-born fertility patterns. Consistent with previous research, we find evidence of a disruption effect on fertility - the fertility of immigrant women in the most recent arrival cohorts is low, but increases at a faster rate relative to both the fertility of immigrants from earlier cohorts and relative to the fertility of natives. We find that immigrants experience lower mortality than native-born individuals in the United States, and these differences remain even after controlling for underlying differences in observable characteristics. However we find that they do not exhibit differences in their subjective expectations of their mortality.
\end{abstract}

\section{Authors’ Acknowledgements}

Corresponding author: Lucie Schmidt; lschmidt@williams.edu; Department of Economics, 201 South Academic Building, 24 Hopkins Hall Drive, Williamstown, MA 01267; 413-597-3143. 


\section{Introduction}

The solvency of the Social Security system in the United States is directly linked to demographic processes such as fertility and mortality that determine the ratio of retirees to workers. Increasing longevity, combined with at or just-below replacement rate fertility, have led to serious concerns about how to finance retiree benefits in the future.

Given this context of demographic changes, policy makers have begun to look at immigrants as a potential means of alleviating the fiscal pressures on the Social Security system (Social Security Advisory Board, 2005). While the Census has developed estimates of the number of immigrants to the United States over the next 50 years under a number of scenarios, the long-term impact of these immigrants on the Social Security system depends critically on their fertility and mortality patterns. Furthermore, mortality differences between immigrant and native-born populations in the US have implications for considerations of equity and progressivity within the Social Security system.

In this project, we use data from a number of sources, including the Decennial Censuses, the American Community Survey, the Health and Retirement Study, and Detail Natality and Mortality files to examine the fertility and mortality patterns of immigrants to the United States. We first examine how the fertility and mortality of immigrants differ from those of the native-born. We then analyze how the fertility and mortality patterns of immigrants vary by a number of demographic and socioeconomic characteristics, as well as by country and region of origin. We also look at how immigrant fertility patterns change over time.

Our fertility results show that immigrants to the United States have significantly higher fertility (both recent and cumulative) than the native born population, but that a large 
share of these differentials can be "explained" by differences in age structure, race and ethnicity, years in the United States, and country of origin. Using a synthetic cohort approach, we examine the role of years in the United States in more detail, and find no evidence of assimilation towards native-born fertility patterns. Consistent with previous research, we find evidence of a disruption effect on fertility - the fertility of immigrant women in the most recent arrival cohorts is low, but increases at a faster rate relative to both the fertility of immigrants from earlier cohorts and relative to the fertility of natives.

We find strong evidence in Vital Statistics data from 2001 that for Whites, Blacks, and Hispanics, immigrants have lower mortality rates than non-immigrants. We continue with a hazard analysis using longitudinal data from the 1992-2004 Health and Retirement Study (HRS) that allows us to follow individuals from when they are first interviewed until death or the end of the sample. These hazard estimates also show a significantly lower hazard of dying among immigrants than non-immigrants. Despite these findings of lower immigrant mortality, when asked questions regarding life expectancy, immigrants in the HRS do not place higher probabilities on their survival than non-immigrants.

\section{Background}

The aging of the US population and its consequences for the Social Security System have been of interest to both researchers and policy-makers for a number of years, as has the issue of whether immigrants to the United States could help to alleviate some of the fiscal pressures on the system. Espenshade (1994) argued that that because immigrants themselves age, immigration cannot do much to address the root cause of population aging -- fertility decline. However, this argument depends critically on the fertility and mortality patterns of 
immigrants and how they differ from the native population. Furthermore, since fertility and mortality patterns may not remain fixed for immigrants and their descendants, the short-term implications of immigration for the population structure may be significantly different from the long-term implications.

Early work by Blau (1992) using the 1970 and 1980 Censuses found relatively small unadjusted immigrant-native differentials in fertility. Work by Kahn (1994) looking at the 1980s found evidence of a growing immigrant-native gap in fertility, and analyzed fertility expectations to shed light on this issue. Both Blau (1992) and Kahn (1994) test to see whether the fertility of immigrants assimilates towards that of the native born with additional years in the US, or whether immigration instead has a disruption effect on fertility, and find evidence of fertility disruption rather than assimilation. ${ }^{1}$ However, a great deal has changed since that time period. Fertility and education patterns of native-born women have changed dramatically (e.g. Goldin and Katz (2002)), as has the composition of immigrants to the United States. More recent work by Swicegood et al. (2006) uses the American Community Survey to show that the total fertility rate of foreign-born women in the US is $27 \%$ higher than that of native-born women, and the general fertility rate is $40 \%$ higher. $^{2}$ Other evidence suggests that foreign-born women in the United States may have higher fertility than their counterparts in the sending country (for the Mexican example see Frank and Heuveline, 2005).

Existing literature on mortality suggests that immigrants to the U.S. have lower mortality rates than the native-born. Singh and Siapush (2001) use data from the 1979-1989 National Longitudinal Mortality Study and find that immigrant men and women have an 18\%

\footnotetext{
${ }^{1}$ However, Mayer and Riphahn (2000) find evidence that immigrants to Germany experience fertility assimilation rather than disruption.

${ }^{2}$ The General Fertility Rate and Total Fertility Rate concepts are explained in detail in Section III.
} 
and $13 \%$ lower risk of mortality, once controlling for covariates. In contrast, Trovato (1993)

finds that in Canada, while overall immigrants to have lower mortality than non-immigrants, at ages older than 60 , immigrants have higher mortality rates than non-immigrants. Other literature on immigrant mortality is limited to populations from specific host countries (e.g. Bradshaw and Frisbie, 1992). ${ }^{3}$

Our analysis of mortality adds to the existing literature by examining a more recent panel of data, which allows us to look at old age mortality among a more recent cohort of individuals. Given the changes over the past few decades in diet, obesity and chronic disease, patterns of mortality risk among different ethnic and racial groups may have changed substantially. In addition, because HRS records the year in which the respondent immigrated, we can also test for assimilation effects. Finally, because HRS asks respondents about their subjective survival probabilities, we can examine mortality expectations.

\section{Fertility}

\section{A. Detail Natality Data}

To analyze fertility, we first use data from the Vital Statistics Detail Natality Data (DND), which provide information on every birth in the United States, and report the birthplace of the mother. We merge these data with the Decennial Censuses from 1990 and 2000 on the populations of both immigrant and native-born women of childbearing age to estimate fertility rates for immigrants and the native-born US population. We calculate General Fertility Rates (GFRs), Age-specific Fertility Rates (ASFRs), and Total Fertility

\footnotetext{
${ }^{3}$ There is a substantial literature documenting immigrant differences in earnings. For some good examples, see Borjas (1987), and Duleep and Regets (1997). Borjas (1999) provides an overview of this literature.
} 
Rates (TFRs) separately for the immigrant population and the native population. The General Fertility Rate is a period fertility measure, and simply measures the number of births divided by the number of women of childbearing age (in this analysis, we define childbearing age to be women ages 15-54). As is illustrated in Table 1, the general fertility rate is significantly higher for immigrant women than for natives (72.8 compared to 46.3 in 2000), although this differential has fallen between 1990 and 2000. However, this measure could provide systematic differences in measured fertility even if actual behavior was identical if the age distributions of the native and immigrant populations differed systematically.

We next present Age-Specific Fertility Rates, which measure the number of births divided by the population of women in 5-year age cohorts. For both 1990 and 2000, the ASFR is higher for immigrants than for natives for every age cohort, but the ratio varies significantly by age cohort. Immigrant fertility is most different from native fertility for the youngest women and the oldest women. In 2000, the AFSRs for immigrant women ages 2039 are between 1.3 and 1.5 times higher than the corresponding AFSRs for native women. However, for immigrant teenagers, the AFSR is 1.6 times higher than the AFSR for native teenagers. For women ages 40-44 and 45-54, the immigrant AFSRs are 1.9 and 2.0 times greater, respectively. When comparing 1990 with 2000, the differentials between the immigrant and native AFSRs have gotten larger for teenagers, but smaller for all other age cohorts. $^{4}$

Finally, we calculate Total Fertility Rates, which are a synthetic cohort measure. The TFR provides the total number of births a woman would have if she lived through her entire reproductive period and was subject to that year's set of age-specific fertility rates. These

\footnotetext{
${ }^{4}$ This is likely related to the large decrease in the birth rates of U.S. teenagers experienced over the 1990s (see for example, Ying, 2008).
} 
fertility rates, for 1990 and 2000, are shown in Table 1. The TFRs of native-born women have remained relatively constant over the time period shown here. In both 1990 and 2000, native TFRs were approximately 1.9 children per women, below the replacement rate of 2.1. For immigrant women, the TFRs are significantly higher, at 3.1 for 1990 and 2.8 for 2000 .

While the Detail Natality Data are particularly useful in that, for the years presented here, they are a 100\% sample of all births in the United States, they do suffer from some limitations when analyzing fertility of immigrants. First, the DND only identify country of origin for immigrants from Mexico, Cuba, and Canada, which somewhat limits a comprehensive analysis of country of origin. In addition, they provide no data on years in the United States for immigrants, which is necessary to identify any type of assimilation effects. As a result of these limitations, we move to other data sources for our analysis.

\section{B. American Community Survey}

The American Community Survey (ACS) is an ongoing survey aimed at collecting Census long-form data on an annual basis. We use data from 2001 and 2002, and our sample of women aged 15-50 consists of 570,284 observations. The ACS asked female respondents of these ages whether they had a birth in the last year. One might be concerned about the accuracy of ACS data on fertility, given that the survey was not designed specifically to measure this behavior. However, Swicegood et al. (2006) compare fertility rates generated from the ACS to Vital Statistics fertility rates published by the National Center for Health Statistics, and show that in general, Total Fertility Rates and General Fertility Rates generated from the ACS line up well with published statistics from NCHS. They conclude that fertility behavior during the previous year is relatively well measured by the ACS. The ACS also 
asked immigrant respondents detailed information about their country of birth, as well as information on their year of arrival in the United States.

We use these data to analyze recent fertility behavior of immigrants and native born in a multivariate framework. In Table 2, we examine how immigrant status affects the probability that a woman reported having a birth in the previous year. Column 1 presents the unadjusted difference, allowing for no control variables. Immigrants are 2 percentage points more likely to have reported a birth in the past year, on a baseline probability of $5.5 \%{ }^{5}$ Column 2 adds basic demographic characteristics of age, age squared, and marital status. Adding these variables reduces the magnitude of the immigrant variable almost by half. However, immigrants are still significantly more likely, by 1.3 percentage points, to have reported a birth in the previous year. The differences between Column 1 and Column 2 are primarily due to the different age distributions among immigrants versus natives (immigrants are likely to be younger and in age groups experiencing higher fertility).

Column 3 adds controls for educational attainment, with dummies for whether the woman was a high school graduate or a college graduate (high school dropout is the omitted category). Once the differences in educational attainment are accounted for between immigrants and natives, the positive immigrant effect on recent fertility actually increases slightly. Column 4 adds controls for region of residence, which do not change the estimated immigrant effect by very much. However, Column 5 adds indicators for race (white and black, with an omitted category of other, as well as Hispanic ethnicity). The inclusion of these control variables reduces the immigrant coefficient again by almost half, so that immigrants, while still statistically more likely to report having a birth in the previous year,

\footnotetext{
${ }^{5}$ Summary statistics for the ACS sample can be found in Appendix Table 1.
} 
are now only 0.7 of a percentage point more likely. Column 6 adds a variable that controls for household income, but this does not change the magnitude of the immigrant effect.

We next fully stratify the sample and run regressions separately by immigrant and native status. Column 1 of Table 3 presents recent fertility regressions for native-born women, while Column 2 presents similar results for immigrant women. In Column 3, we examine the effect of years in the United States on the recent fertility of immigrant women. We find that, compared with immigrant women who have been in the U.S. for less than ten years, women who have been in the country for longer than ten years are significantly less likely to have reported a birth in the past year. Women in the country between 11-20 years are approximately 1.3 percentage points less likely to have had a birth in the previous year when compared to the most recent immigrants.

In Column 4, we add controls for place of birth. We collapse all of the countries of birth identified by the ACS into 9 categories. Compared to the omitted category of other North America, women born in the Central America/Caribbean region and in Africa are statistically more likely to report having a birth in the previous year, by 1.4 and 1.7 percentage points respectively. Women from East Asia are statistically less likely to report having a birth in the previous year, by 1.2 percentage points. ${ }^{6}$ In results not presented here, we allow for a separate effect for each detailed birthplace identified by the ACS. Both Mexico and Central America show significantly higher fertility than the omitted country of Canada, as do Cambodia and Laos. Countries associated with significantly lower fertility are primarily

\footnotetext{
6 “Other North America” includes Canada and the Atlantic Islands. “Central America/Caribbean” includes Mexico, all Central American countries, Cuba, and the West Indies. "Europe” includes all countries in Northern, Western, Southern, Central/Eastern Europe, as well as Russia and the Baltic States. "East Asia” includes China, Japan, and Korea, while "South Asia” includes countries in both Southeast and Southwest Asia, such as Cambodia, Indonesia, Malaysia, the Philippines, Singapore, Thailand, Vietnam, Afghanistan, India, the Maldives, and Nepal. "Rest of Asia” primarily includes the Middle East and Turkey. "Oceania” includes Australia, New Zealand, and the Pacific Islands.
} 
those countries in Southern and Eastern Europe that are experiencing low fertility at home immigrant women from Albania, Greece, Bulgaria, and Czechoslovakia, Poland, Yugoslavia, and other former Soviet Socialist Republics are all significantly less likely to have reported a birth in the previous year. ${ }^{7}$

It is unclear how our results on years in the United States should be interpreted. Previous research on immigrants and fertility (Blau, 1992; Kahn, 1994) has suggested that immigrant fertility could change over time in the US in several different ways. The assimilation hypothesis would suggest that the fertility of immigrants to the United States (particularly those coming from high fertility countries of origin) is high shortly after arrival, but then falls over years in the United States and converges towards the fertility of native born women. An alternative theory - the disruption hypothesis - would suggest that the act of immigration depresses fertility temporarily. The disruption hypothesis suggests that the fertility of immigrants should increase with years in the United States relative to that of natives. Our findings in the ACS on years in the US - that the fertility of those immigrants who have been in the US longer is lower than that of recent immigrants - could be interpreted as potential evidence of the assimilation hypothesis.

However, as made clear by Borjas (1987), with only one cross-section of data, it impossible to disentangle the effect of years in the US from the effect of cohort of entry. By using multiple cross-sections, we can employ the synthetic cohort methodology of Borjas (1987) to separately identify cohort versus time in the US effects. ${ }^{8}$ Previous work using this

\footnotetext{
${ }^{7}$ Results available from authors. Czech Republic and Slovakia are still reported in ACS data as Czechoslovakia, and the ACS still report data from Yugoslavia. Individual countries in Africa are not separately identified in the ACS data.

${ }^{8}$ The synthetic cohort approach has its own limitations, outlined by Jasso (2004). First, there may be problems with the Census question on year of entry to the United States. The wording of the question has changed over the Censuses between 1980 and 2000. Even holding the wording of the question constant, Jasso (2004) argues that it may be answered differently depending on legal status or the time it is asked over the lifecycle. In
} 
approach (by Blau using the 1970 and 1980 Censuses, and by Kahn using the 1980 Census and the 1986-88 Current Population Surveys) provides evidence consistent with fertility disruption rather than assimilation, but a similar analysis has not been done with more recent data. We therefore next turn to the Census to do an analysis of data from 1990 and 2000.

\section{Decennial Census, 1990 and 2000}

In this section, we use data from the 1990 and 2000 Decennial Censuses to examine the fertility of immigrant versus native women. In the previous section, we used the ACS to analyze recent fertility - whether a woman reported having a birth in the previous year. Here, using the Census, we look at a total cumulative measure of fertility - the Census variable nchild, which represents the number of the woman's own children of any age living in the household with her. This variable is a flawed measure of total fertility. It would underestimate fertility if women had given birth to children that were no longer in the household, either because they were now grown, or because they were living with other adults. It would overestimate fertility due to adoption. It would be preferable to use the Census variable chborn, which reports the number of children ever born to each woman. However, the 2000 Census removed the chborn variable. Calculations from the 1990 Census, which included both variables, suggest errors in classification in both directions from using the nchild variable. However, the bias does not seem to differ between immigrants and natives, so we use the nchild variable here.

Table 4 examines the immigrant-native differential in the number of own children in the Decennial Census for both 2000 (Panel A) and 1990 (Panel B). For the 2000 data, 
immigrants reported 0.32 more children than natives (Column 1). However, this differential drops dramatically as additional control variables are introduced in Columns 2-6, in much the same way that the differential fell in Table 2 using the ACS. Adding age and marital status causes the immigrant effect to fall by almost one half. Adding educational attainment, region of residence, and household income do not qualitatively change the immigrant effects, but the addition of race and ethnicity in Column 5 does have a large effect on the immigrant differential.

In Table 5, we stratify the 2000 Census regressions by immigrant/native status, and then add controls for years in the US and country of birth to the immigrant regressions. While our place of birth results in Column 4 are largely consistent with the place of birth results from the ACS analysis presented above, the years in the US coefficients suggest that those in the US for longer have higher total fertility than the most recent immigrants.

In Table 6, we adopt the synthetic cohort analysis of Borjas (1987), which has also been used in immigrant fertility analyses by both Blau (1992) and Kahn (1994). For this analysis, we limit our sample to women who were born in the years 1956-1975. These women are aged 15-34 in the 1990 Census, and are 25-44 in the 2000 Census. For the immigrants in our sample, we limit to those immigrants who had arrived in the US by 1990. Columns 1 and 2 present the average number of children in 1990 and 2000, unadjusted for any of differences in characteristics between the two groups. We first present the results separately for native-born and immigrant women, and then look at the immigrant women separately by year of arrival into the United States. These results show that the number of children for immigrant women is higher than that of native-born women, and that the immigrant-native differential is growing over the 1990s. The number of children for native 
women increases by 0.55 child between 1990 and 2000, while for immigrant women it increases by 0.84 child. Looking at the immigrants separately by their year of arrival, we see that the number of children is the lowest in 1990 for the most recent immigrants (those who arrived in the country between 1985-1989, but that the fertility of this group increases the most rapidly over the 1990s. Columns 3 and 4 present the predicted number of children for each group in 1990 and 2000, adjusting these predictions for the model control variables and the characteristics of the total immigrant sample. ${ }^{9}$ While adjusting for these characteristics reduces the gap between immigrant and native fertility, these results provide strong evidence for the fertility disruption process, in that the fertility of immigrants grows more rapidly than that of the native-born, and that the fertility of the most recent immigrants (those most likely to have had their fertility recently disrupted by the immigration process) grows the most quickly. These results, suggestive of fertility disruption rather than fertility assimilation, are consistent with the earlier findings of both Blau (1992) and Kahn (1994).

\section{Mortality}

\section{A. Detail Mortality Data}

We first examine immigrant and native mortality rates using the Vital Statistics Detail Mortality Data (DMD) from the National Center for Health Statistics. The DMD compile data from death certificate filings to provide data on all the deaths which occurred in the United States in a given year. This large data set is ideal for making population comparisons of mortality by immigrant status. We merge the DMD with the Decennial Census so that we can calculate death rates for immigrants and non-immigrants by age. We use data from the 2000

\footnotetext{
${ }^{9}$ These results are adjusted for age, age squared, education, marital status, race, ethnicity, region of residence, and household income.
} 
Census to calculate the number of immigrants and non-immigrants by age and race alive in 2000. We then calculate the number of deaths among immigrants and non-immigrants by age and race in 2001. We merge these counts across both samples to calculate age and race specific one-year mortality rates, separately for immigrants and non-immigrants.

Figures 1 and 2 present plots of mortality rates by age and immigration status, for men and women respectively. Among both men and women, immigrants have noticeably lower mortality rates than non-immigrants, across most of the age distribution. For example, at age 70, immigrant men have a 2 percent chance of dying before reaching age 71 . The one-year mortality rate of U.S. born men at that age is 50 percent higher at 3 percent. U.S. born women also face a one-year mortality rate (1.8 percent) that is $50 \%$ higher than that of foreign born women at age 70 (1.2 percent). We next look at whether these differences exist across all races and ethnicities. Figures 3a and 3b plot mortality rates by immigrant status for Whites, Figures $4 \mathrm{a}$ and $4 \mathrm{~b}$ for Blacks, and Figures $5 \mathrm{a}$ and $5 \mathrm{~b}$ for Hispanics. They show that White, Black and Hispanic immigrants have lower one-year mortality rates than U.S. born men and women of the same race or ethnicity. There is no immigrant differential among individuals of other races (not shown).

The plots are generally consistent with the conventional wisdom that Whites have higher life expectancy than other racial or ethnic groups. However, they also show important variation by race and immigration status. Figures $6 \mathrm{a}$ and $6 \mathrm{~b}$ illustrate this by comparing U.S. born and foreign born Hispanic males to White males born in the U.S. While U.S. born Hispanic men have higher mortality rates that U.S. born Whites, immigrant Hispanic men 
have lower mortality rates than White men. Similar patterns are seen for Black men and women and Hispanic women. ${ }^{10}$

Because the DMD do not have detailed characteristics of the deceased, it is impossible to know whether the lower mortality rates observed among immigrants is due to underlying differences in characteristics known to affect mortality, such as health or income. To try and control for such factors, we turn to the Health and Retirement Study.

\section{B. Health and Retirement Study}

The Health and Retirement Study (HRS) is a longitudinal study of individuals ages 51 and older. It began in 1992 by surveying individuals born between 1931 and 1941 (ages 51 to 61) and their spouses. In 1998 it merged with the AHEAD study, which had begun in 1993 as a longitudinal study of individuals born in 1923 or earlier (ages 70 and older) and their spouses. Also in 1998, HRS added the cohort of individuals born between 1923 and 1931 and between 1942 and 1947. Since then subsequent cohorts of individuals are added every six years, so that the sample remains a representative sample of older individuals. ${ }^{11}$

About 10 percent of the roughly 30,000 individuals ever interviewed by HRS/AHEAD are foreign born. Because about a third of all respondents have died by 2006, the HRS allows an analysis of mortality patterns. This rate clearly varies a great deal by cohort, with about 64 percent of the AHEAD cohort - first interviewed in 1993 when aged 70 or older, deceased by 2006.

\footnotetext{
${ }^{10}$ These results are consistent with evidence in Antecol and Bedard (2006) that suggests that immigrants to the US retain eating and other health patterns of their home nations, while first-generation US born tend to converge to (less healthy) US habits.

${ }^{11}$ For more information about the HRS please see http://hrsonline.isr.umich.edu/intro/sho_uinfo.php?hfyle=sample_new_v3\&xtyp=2
} 
Because a substantial portion of the sample has not died, our ability to study their mortality is limited. One advantage of the HRS is therefore the ability to study expectations of life expectancy, because the HRS asks a number of questions on subjective survival probabilities. In each wave, respondents report their expected probability of living to particular ages. These questions have been studied extensively and are in general found to have significant predictive power (e.g. Hurd and McGarry, 2002). Thus, they allow us to examine differences in mortality expectations for the non-deceased. In the analysis that follows, we separately estimate mortality hazards and regressions of subjective survival probabilities for HRS respondents.

The HRS documents the deaths of all respondents that have ever been interviewed, regardless of whether they stopped responding to the survey prior to their death. HRS is able to do this through the National Death Index (NDI), a computerized index of deaths in the U.S. The National Center for Health Statistics collects the NDI data from State Vital Statistics offices. ${ }^{12}$ We use these data to estimate proportional hazard models on the months until death since the HRS respondent was first interviewed, separately for men and women. We measure survival up to 2004 because that is the last year for which HRS currently has NDI data. We include a dummy variable for whether the respondent is an immigrant and we also control for a number of respondent characteristics, as observed when they were first interviewed. These include age, age squared, Black race, Hispanic ethnicity, years of education, household income, and health insurance coverage.

Appendix Table 3 presents summary statistics on the HRS sample we use to study actual mortality. We exclude individuals who are below age 51 and those who have missing

\footnotetext{
${ }^{12}$ More information on the NDI is available on the NCHS website http://www.cdc.gov/nchs/r\&d/ndi/what_is_ndi.htm.
} 
data for the variables we use. The average age at which immigrants moved to the US is approximately 30, although there is substantial variation in age at entry in the sample. Immigrant men (but not women) have significantly higher household income than nonimmigrant men, although this is partly due to outliers among the immigrant sample. A significantly greater share of immigrants is without any health insurance (either private or public).

Table 7 presents odds ratios of the hazard of death. We first present estimates that do not control for household income and health insurance coverage, because these variables could be correlated with unobserved factors which may directly be related to mortality risk. Column 1 presents these estimates. Consistent with the data in the DND, and the existing literature on U.S. immigrants, we find that immigrant status associated with a significantly lower mortality hazard for both men and women. Immigrant men have a 44 percent lower hazard than non-immigrant men, and immigrant women have a 41 percent lower hazard. ${ }^{13}$ The estimates on other coefficients are as expected - Blacks have a higher hazard relative to Whites, an additional year of education lowers one's hazard, and each additional year of age increases the hazard. Among women, Hispanics also have a lower hazard relative to nonHispanics. Column 2 adds an additional control for the age at which the respondent immigrated. It equals zero for U.S. born respondents. Its estimate does not provide any evidence of assimilation effects.

Column 3 adds the natural log of household income. It also adds a measure of health insurance coverage (whether the respondent has coverage either from Medicare or private health insurance). Not surprisingly, higher income and health insurance both reduce the

\footnotetext{
${ }^{13}$ The marginal effect of being an immigrant on the hazard is obtained by subtracting the estimated odds-ratio from one of the odds-ratio is less than one, and by subtracting one from the odds-ratio if it is greater than one.
} 
mortality hazard. Controlling for these resources also lowers the estimated effect of being an immigrant (i.e. it raises the odds ratio) so that immigrant men and women are estimated to have a 31 percent and 34 percent lower mortality risk than non-immigrants, respectively. In contrast, Singh and Siapush (2001) find that socioeconomic differences between immigrants and natives do not explain much of the mortality differential observed over the 1980s.

Likewise, Heron, Schoeni, and Morales (2002) find that socioeconomic differences between the two groups explain little of the immigrant-native differential in health status.

We next examine whether immigrants place different subjective probabilities on survival than non-immigrants. In each wave, the HRS asks a number of questions on expectations and life expectancy questions are one set of them. Respondents ages 65 or younger are asked to report "What do you think are the chances that you will live to be 75 or more?” or a similarly worded question. ${ }^{14}$ In the first four waves (1992-1998), respondents ages 75 or younger were then asked about the percent chance that they would live to age 85 or older. ${ }^{15}$ In subsequent waves, HRS changed the second question to ask about the percent chance that the respondent would live to be some age that was ten to 15 years older than their current age. ${ }^{16}$ The second question was asked of all respondents ages 90 or younger in HRS 2000 and all subsequent waves. In 1992, respondents report the probability on a scale from 0 to 10 . In subsequent waves, they report a percent from 0 to 100 . For the analysis that follows, we multiply the 1992 response by 10 to allow us to pool responses to it with those from later year.

\footnotetext{
14 The question wording changes slightly across waves.

${ }^{15}$ Respondents ages 65 and younger were asked both questions, provided that they provided a non-zero response to the age 75 question.

${ }^{16}$ Respondents were asked about survival to the following ages based on their current age as follows: current age 69 or less: age $80+$, current age 70-74: age 85+, current age 75-79: age 90+, current age 80-84: age 95+, current age 85-89: age $100+$.
} 
For each of the three survival probability questions, we estimate OLS regressions separately for men and women. We pool observations from all of the relevant waves and cluster standard errors at the individual level to adjust for the fact that there are multiple observations per person. We include year fixed effects and controls for age, age at immigration (which equals zero for non-immigrants), self-reported health status, Black race, Hispanic ethnicity, years of education, marital status, household income, and health insurance coverage. ${ }^{17,18}$ Table 8 presents these results. In contrast with the hazard model results and the DND data, immigrants do not report higher survival probabilities. Though the estimated coefficients are generally positive, they are small and not statistically different from zero. This is surprising given the literature which documents that these questions are good predictors of future survival. It is possible that immigrants systematically underestimate their life expectancy due perhaps to lower life expectancies in their source countries. However, if this was the case, we might expect evidence of assimilation effects, and the estimated coefficients on age at immigration are consistently small in magnitude and statistically insignificant.

The estimated coefficients on many of the covariates are in the expected direction. Greater age and additional years of education are associated with a higher expected probability of reaching a given age. Worse self reported health (excellent health is the reference group) is associated with much lower subjective survival probabilities. However, one surprise is that Blacks report significantly higher subjective probabilities of survival than Whites, which is inconsistent with observed differences in actual mortality risks.

\footnotetext{
${ }^{17}$ We also estimate these regressions while excluding controls and because the results are quite similar we do not present them.

${ }^{18}$ Appendix Table 4 presents additional summary statistics for the HRS, but for the sample of pooled observations across the years used to study subjective survival probabilities.
} 


\section{Summary}

In 2003, the foreign-born population in the United States was 33.5 million, representing $11.7 \%$ of the population (Larsen, 2004). However, this population made up a quarter of all births in the United States in the same year (Martin et al., 2005). Given concerns about the aging of the US population and the solvency of the Social Security system, understanding how immigrants to the United States affect the age distribution of the population has become increasingly important. Despite this, little work has been done to inform policy makers of how immigrants may affect Social Security.

This paper uses population and survey data to examine differential patterns of fertility and mortality between immigrants and the native-born. Our fertility results show that immigrants to the United States have significantly higher fertility (both recent and cumulative) than the native born population, but that a large share of these can be "explained" by differences in age structures, race and ethnicity, years in the United States, and country of origin. Using a synthetic cohort approach, we examine the role of years in the United States in more detail, and find no evidence of assimilation towards native-born fertility patterns. Consistent with previous research, we find evidence of a disruption effect on fertility - the fertility of immigrant women in the most recent arrival cohorts is low, but increases at a faster rate relative to both the fertility of immigrants from earlier cohorts and relative to the fertility of natives.

Our analysis of actual mortality in the Vital Statistics and HRS provides strong evidence that immigrants have lower mortality rates than the US born. This difference is qualitatively and statistically significant even when controlling for differences in education, 
income, and health insurance coverage. These results could reflect selection effects. Because individuals who actually leave their source countries may need greater resources to leave, it could be the case that the smartest and healthiest individuals are the ones leave and immigrate to the U.S. U.S. immigration policies, which have varied over time and across countries, could also enforce this selection effect. Interestingly, despite the differentials in actual mortality, immigrants in the same HRS sample do not exhibit higher subjective survival probabilities than the US born.

These differences in fertility and mortality have important implications for discussions related to the solvency of the Social Security system. Furthermore, mortality differences between immigrant and native-born populations in the US have implications for considerations of equity and progressivity within the Social Security system. Our results suggest that holding income or Social Security contributions constant, immigrants get a higher return on Social Security than non-immigrants. Furthermore, since lifetime Social Security contributions are on average lower among immigrants, due to fewer years of covered earnings in the U.S. on average they could realize an even greater return than non-immigrants. This is consistent with findings in Gustman and Steinmeier (2000). However as we show in earlier work (Sevak and Schmidt, 2008), immigrants enter retirement with significantly lower Social Security benefits than non-immigrants. Given the intended progressivity of the Social Security system, the documented differences in demographic outcomes should be taken into account when considering changes to Social Security or immigration policy. 


\section{References}

Antecol, Heather and Kelly Bedard. 2006. "Unhealthy Assimilation: Why Do Immigrants Converge to American Health Status Levels?” Demography 43(2): 337-60.

Blau, Francine D. 1992. "The Fertility of Immigrant Women: Evidence from High Fertility Source Countries.” In Borjas and Freeman, eds. Immigration and the Workforce. Chicago, IL: University of Chicago Press.

Borjas, George. 1999. "The Economic Analysis of Immigration," in The Handbook of Labor Economics, Volume 3A, edited by Orley Ashenfelter and David Card, North-Holland, pp. 1697-1760.

Borjas, George. 1987. "Self-Selection and the Earnings of Immigrants.” American Economic Review 77: 531-53.

Bradshaw, Benjamin S. and W. Parker Frisbie. 1992. "Mortality of Mexican Americans and Mexican Immigrants: Comparisons with Mexico.” Demographic dynamics of the U.S.-Mexico border, pp. 125-50, El Paso: Texas Western Press

Duleep, Harriet and Mark Regets. 1997. "Measuring Immigrant Wage Growth Using Matched CPS Files," Demography 34: 239-49.

Espenshade, TJ. 1994. “Can Immigration Slow Population Aging?” Journal of Policy Analysis and Management 13: 759-68.

Fernandez, Raquel and Alessandra Fogli. 2005. "Fertility: The Role of Culture and Family Experience.” NBER working paper \#11569

Frank, Reanne and Patrick Heuveline. 2005. "A Crossover in Mexican and MexicanAmerican Fertility Rates: Evidence and Explanations for an Emerging Paradox.” Demographic Research 12: 77-104.

Goldin, Claudia and Lawrence F. Katz. 2002. "The Power of the Pill: Oral Contraceptives and Women’s Career and Marriage Decisions.” Journal of Political Economy 110(4): 730-70.

Gustman, Alan and Thomas Steinmeier. 2000. "Social Security Benefits of Immigrants and US Born.” In George Borjas, editor, Issues in the Economics of Immigration, University of Chicago Press, pp. 309-350.

Heron, Melonie P., Robert F. Schoeni, and Leo Morales. 2002. "Health Status of Older Immigrants in the U.S.” RAND Labor and Population Program Working Paper 02-07.

Hurd, Michael D. and Kathleen McGarry. 2002. "The Predictive Validity of Subjective Probabilities of Survival.” The Economic Journal 112 (482), 966-985 
Jasso, Guillermina. 2004. “Comment on Greulich, Quigley, and Raphael.” BrookingsWharton Papers on Urban Affairs: 188-203.

Kahn, Joan R. 1994. "Immigrant and Native Fertility During the 1980s: Adaptation and Expectations for the Future.” International Migration Review. 28(3): 501-19.

Larsen, Luke J. 2004. The Foreign Born Population in the United States: 2003. Current Population Reports, P20-551, U.S. Census Bureau, Washington, DC.

Lee, Ronald. 2000. "Long-term Population Projections and the US Social Security System.” Population and Development Review 26(1): 137-43.

Martin, Joyce A., Brady E. Hamilton, Paul D. Sutton, Stephanie J. Ventura, Fay Menacher, and Martha L. Munson. 2005. Births: Final Data for 2003. National Vital Statistics Reports 54(2). Hyattsville, MD: NCHS.

Mayer, Jochen and Regina T. Riphahn. 2000. "Fertility Assimilation and Immigrants: Evidence from Count Data Models.” Journal of Population Economics 13: 241-61.

Sevak, Purvi and Lucie Schmidt. 2008. “How Do Immigrants Fare in Retirement?” Hunter College and Williams College Unpublished Draft.

Singh, Gopal K. and Mohammad Siahpush. 2001. "All-Cause and Cause-Specific Mortality of Immigrants and Native Born in the United States." American Journal of Public Health 91(3): 392-99.

Feinleib, Joel and David Warner. 2005. "The Impact of Immigration on Social Security and the National Economy.” Social Security Advisoty Board Issue Brief\#1.

Swicegood, C Gray, Michael Sobczak, and Hiromi Ishizawa. 2006. "A New Look at the Recent Fertility of American Immigrants, Results for the $21^{\text {st }}$ Century.” Paper presented at the 2006 Annual Meetings of the Population Association of America, Los Angeles.

Trovato, F. 1993. "Differential Mortality Between Immigrants and the Canadian-born, 19851987: General and Cause-Specific.” Paper presented at the 1993 International Population Conference, Montreal, Canada.

Ying, Zhichun. 2008. "What Contributed To The Racial Difference In Declining Teenage Fertility Rates In The U.S. After 1991?” Williams College Unpublished Manuscript. 
Table 1: Fertility Rates

\begin{tabular}{|c|c|c|c|c|}
\hline & \multicolumn{2}{|c|}{1990} & \multicolumn{2}{|c|}{2000} \\
\hline & Immigrant & Native-Born & Immigrant & Native-Born \\
\hline $\begin{array}{l}\text { General Fertility Rate } \\
\text { (per 1,000 women) }\end{array}$ & 85.7 & 55.0 & 72.8 & 46.3 \\
\hline $\begin{array}{l}\text { Age-Specific Fertility Rates } \\
\text { (per } 1,000 \text { women) }\end{array}$ & & & & \\
\hline Ages 15-19 & 82.2 & 58.7 & 74.9 & 45.6 \\
\hline Ages 20-24 & 176.8 & 113.1 & 146.1 & 103.0 \\
\hline Ages 25-29 & 171.4 & 114.6 & 147.6 & 107.4 \\
\hline Ages 30-34 & 120.2 & 75.1 & 117.6 & 86.7 \\
\hline Ages 35-39 & 55.7 & 28.9 & 56.6 & 35.6 \\
\hline Ages 40-44 & 12.2 & 4.6 & 13.5 & 6.9 \\
\hline Ages 45-54 & 0.46 & 0.09 & 0.51 & 0.20 \\
\hline $\begin{array}{l}\text { Total Fertility Rate } \\
\text { (per woman) }\end{array}$ & 3.10 & 1.98 & 2.77 & 1.93 \\
\hline
\end{tabular}

Notes: Numerators calculated from Vital Statistics Detail Natality Data. Denominators calculated from Decennial Census IPUMS Data. Women born in U.S. outlying areas/territories are excluded. 
Table 2: Relationship between Immigrant Status and Recent Fertility, Using American Community Survey 2001-2002

\begin{tabular}{|c|c|c|c|c|c|c|}
\hline & Raw difference & $\begin{array}{c}\text { Adding } \\
\text { demographics }\end{array}$ & $\begin{array}{c}\text { Adding } \\
\text { educational } \\
\text { attainment }\end{array}$ & $\begin{array}{c}\text { Adding region } \\
\text { of residence }\end{array}$ & $\begin{array}{l}\text { Adding race } \\
\text { and ethnicity }\end{array}$ & $\begin{array}{c}\text { Adding } \\
\text { household } \\
\text { income }\end{array}$ \\
\hline & (1) & (2) & (3) & (4) & (5) & (6) \\
\hline Immigrant & $\begin{array}{c}0.0228 * * * \\
(0.0009)\end{array}$ & $\begin{array}{c}0.0127 * * * \\
(0.0009)\end{array}$ & $\begin{array}{c}0.0137 * * * \\
(0.0009)\end{array}$ & $\begin{array}{c}0.0142 * * * \\
(0.0009)\end{array}$ & $\begin{array}{c}0.0074 * * * \\
(0.0010)\end{array}$ & $\begin{array}{c}0.0071 * * * \\
(0.0010)\end{array}$ \\
\hline Age & -- & $\begin{array}{c}0.0108 * * * \\
(0.0002)\end{array}$ & $\begin{array}{c}0.0096 * * * \\
(0.0002)\end{array}$ & $\begin{array}{c}0.0096 * * * \\
(0.0002)\end{array}$ & $\begin{array}{c}0.0090 * * * \\
(0.0002)\end{array}$ & $\begin{array}{c}0.0082 * * * \\
(0.0002)\end{array}$ \\
\hline Age squared & -- & $\begin{array}{l}-0.0002 * * * \\
(3.14 \mathrm{e}-06)\end{array}$ & $\begin{array}{c}-0.0002^{* * *} \\
(3.43 \mathrm{e}-06)\end{array}$ & $\begin{array}{l}-0.0002 * * * \\
(3.43 \mathrm{e}-06)\end{array}$ & $\begin{array}{l}-0.0002 * * * \\
(3.44 \mathrm{e}-06)\end{array}$ & $\begin{array}{r}-0.0002 * * * \\
(3.47 \mathrm{e}-06)\end{array}$ \\
\hline Married & -- & $\begin{array}{c}0.0664 * * * \\
(0.0007)\end{array}$ & $\begin{array}{c}0.0661 * * * \\
(0.0007)\end{array}$ & $\begin{array}{c}0.0658 * * * \\
(0.0007)\end{array}$ & $\begin{array}{c}0.0688 * * * \\
(0.0007)\end{array}$ & $\begin{array}{c}0.0716 * * * \\
(0.0007)\end{array}$ \\
\hline High School Graduate & -- & -- & $\begin{array}{c}0.0087 * * * \\
(0.0010)\end{array}$ & $\begin{array}{c}0.0089 * * * \\
(0.0010)\end{array}$ & $\begin{array}{c}0.0115 * * * \\
(0.0010)\end{array}$ & $\begin{array}{c}0.0121^{* * *} \\
(0.0010)\end{array}$ \\
\hline College Graduate & -- & -- & $\begin{array}{c}0.0137 * * * \\
(0.0011)\end{array}$ & $\begin{array}{c}0.0143 * * * \\
(0.0011)\end{array}$ & $\begin{array}{c}0.0191 * * * \\
(0.0011)\end{array}$ & $\begin{array}{c}0.0238 * * * \\
(0.0011)\end{array}$ \\
\hline $\begin{array}{l}\text { Region of Residence } \\
\text { Dummies }\end{array}$ & No & No & No & Yes & Yes & Yes \\
\hline $\begin{array}{l}\text { Race and Ethnicity } \\
\text { Dummies }\end{array}$ & No & No & No & No & Yes & Yes \\
\hline Household Income & No & No & No & No & No & Yes \\
\hline $\mathrm{N}$ & 570,284 & 570,284 & 570,284 & 570,284 & 570,284 & 570,284 \\
\hline
\end{tabular}


Table 3: ACS Analysis of Recent Fertility, Stratified by Immigrant Status

\begin{tabular}{|c|c|c|c|c|}
\hline & Natives & Immigrants & $\begin{array}{l}\text { Immigrants, + } \\
\text { years in US }\end{array}$ & $\begin{array}{c}\text { Immigrants, }+ \\
\text { birthplace }\end{array}$ \\
\hline Age & $\begin{array}{c}0.0075 * * * \\
(0.0002)\end{array}$ & $\begin{array}{l}0.0118 * * * \\
(0.0008)\end{array}$ & $\begin{array}{c}0.0119 * * * \\
(0.0008)\end{array}$ & $\begin{array}{l}0.0116 * * * \\
(0.0008)\end{array}$ \\
\hline Age squared & $\begin{array}{c}-0.0002^{* * *} \\
(3.64 \mathrm{e}-06)\end{array}$ & $\begin{array}{c}-.00002 * * * \\
(0.00001)\end{array}$ & $\begin{array}{c}-0.0002 * * * \\
(0.00001)\end{array}$ & $\begin{array}{c}-0.0002 * * * \\
(0.00001)\end{array}$ \\
\hline Married & $\begin{array}{c}0.0708 * * * \\
(0.0007)\end{array}$ & $\begin{array}{c}0.0767 * * * \\
0.0023\end{array}$ & $\begin{array}{c}0.0758 * * * \\
(0.0023)\end{array}$ & $\begin{array}{c}0.0754 * * * \\
(0.0023)\end{array}$ \\
\hline High School Graduate & $\begin{array}{c}0.0155^{* * *} \\
(0.0010)\end{array}$ & $\begin{array}{c}0.0004 \\
(0.0026)\end{array}$ & $\begin{array}{c}0.0006 \\
(0.0027)\end{array}$ & $\begin{array}{c}0.0029 \\
(0.0027)\end{array}$ \\
\hline College Graduate & $\begin{array}{c}0.0286 * * * \\
(0.0012)\end{array}$ & $\begin{array}{c}0.0043 \\
(0.0032)\end{array}$ & $\begin{array}{c}0.0036 * * * \\
(0.0032)\end{array}$ & $\begin{array}{l}0.0067 * * \\
(0.0032)\end{array}$ \\
\hline White & $\begin{array}{c}-0.0068^{* * *} \\
(0.0014)\end{array}$ & $\begin{array}{l}-0.0017 \\
(.0021)\end{array}$ & $\begin{array}{l}-0.0022 \\
(0.0021)\end{array}$ & $\begin{array}{l}-0.0023 \\
(0.0027)\end{array}$ \\
\hline Black & $\begin{array}{c}0.0172 * * * \\
(0.0017)\end{array}$ & $\begin{array}{c}0.0257 * * * \\
(0.0041)\end{array}$ & $\begin{array}{c}0.0258 * * * \\
(0.0041)\end{array}$ & $\begin{array}{c}0.0099 * \\
(0.0057)\end{array}$ \\
\hline Hispanic & $\begin{array}{c}0.0139 * * * \\
(0.0015)\end{array}$ & $\begin{array}{c}0.0201 * * * \\
(0.0023)\end{array}$ & $\begin{array}{c}0.0205 * * * \\
(0.0023)\end{array}$ & $\begin{array}{c}0.0071 \\
(0.0050)\end{array}$ \\
\hline \multicolumn{5}{|c|}{ Years in USA (omitted category 0-5) } \\
\hline $6-10$ years & -- & -- & $\begin{array}{c}0.0035 \\
(0.0031)\end{array}$ & $\begin{array}{c}0.0030 \\
(0.0031)\end{array}$ \\
\hline 11-15 years & -- & -- & $\begin{array}{c}-0.0130 * * * \\
(0.0031)\end{array}$ & $\begin{array}{c}-0.0135 * * * \\
(0.0031)\end{array}$ \\
\hline $16-20$ years & -- & -- & $\begin{array}{c}-0.0126 * * * \\
(0.0035)\end{array}$ & $\begin{array}{c}-0.0130 * * * \\
(0.0035)\end{array}$ \\
\hline $21+$ years & -- & -- & $\begin{array}{c}-0.0062 * * \\
(0.0030)\end{array}$ & $\begin{array}{c}-0.0066 * * \\
(0.0030)\end{array}$ \\
\hline \multicolumn{5}{|c|}{ Place of Birth (other North America omitted) } \\
\hline $\begin{array}{l}\text { Central } \\
\text { America/Caribbean }\end{array}$ & -- & -- & -- & $\begin{array}{l}0.0138 * \\
(0.0074)\end{array}$ \\
\hline South America & -- & -- & -- & $\begin{array}{l}-0.0069 \\
(0.0076)\end{array}$ \\
\hline Europe & -- & -- & -- & $\begin{array}{l}-0.0075 \\
(0.0060)\end{array}$ \\
\hline East Asia & -- & -- & -- & $\begin{array}{l}-0.0119 * \\
(0.0066)\end{array}$ \\
\hline South Asia & -- & & & $\begin{array}{l}-0.0005 \\
(0.0064)\end{array}$ \\
\hline Rest of Asia & -- & -- & -- & $\begin{array}{c}0.0082 \\
(0.0089)\end{array}$ \\
\hline Africa & -- & -- & -- & $\begin{array}{l}0.0170 * * \\
(0.0084)\end{array}$ \\
\hline Oceania & -- & -- & -- & $\begin{array}{l}-0.0097 \\
(0.0127)\end{array}$ \\
\hline
\end{tabular}

Notes: Regressions control for region of residence and household income. 
Table 4: Relationship between Immigrant Status and Number of Own Children, Using Decennial Census for 2000 and 1990

\begin{tabular}{|c|c|c|c|c|c|c|}
\hline & Raw difference & $\begin{array}{c}\text { Adding } \\
\text { demographics }\end{array}$ & $\begin{array}{c}\text { Adding } \\
\text { educational } \\
\text { attainment }\end{array}$ & $\begin{array}{l}\text { Adding region } \\
\text { of residence }\end{array}$ & $\begin{array}{l}\text { Adding race } \\
\text { and ethnicity }\end{array}$ & $\begin{array}{c}\text { Adding } \\
\text { household } \\
\text { income } \\
\end{array}$ \\
\hline A. 2000 & (1) & (2) & (3) & (4) & (5) & (6) \\
\hline Immigrant & $\begin{array}{c}0.3139 * * * \\
(0.0039)\end{array}$ & $\begin{array}{c}0.1770 * * * \\
(0.0034)\end{array}$ & $\begin{array}{c}0.1102 * * * \\
(0.0034)\end{array}$ & $\begin{array}{c}0.1097 * * * \\
(0.0035)\end{array}$ & $\begin{array}{c}0.0322 * * * \\
(0.0040)\end{array}$ & $\begin{array}{c}0.0312^{* * *} \\
(0.0040)\end{array}$ \\
\hline $\mathrm{N}$ & 792,611 & 792,611 & 792,611 & 792,611 & 792,611 & 792,611 \\
\hline $\begin{array}{l}\text { B. } 1990 \\
\text { Immigrant }\end{array}$ & $\begin{array}{c}0.2345 * * * \\
(0.0050)\end{array}$ & $\begin{array}{c}0.1619 * * * \\
(0.0043)\end{array}$ & $\begin{array}{l}0.1006 * * * \\
(0.0043)\end{array}$ & $\begin{array}{c}0.1170 * * * \\
(0.0044)\end{array}$ & $\begin{array}{c}0.0153 * * * \\
(0.0049)\end{array}$ & $\begin{array}{c}0.0168 * * * \\
0.0049\end{array}$ \\
\hline $\mathrm{N}$ & 700,801 & 700,801 & 700,801 & 700,801 & 700,801 & 700,801 \\
\hline
\end{tabular}


Table 5: 2000 Census Analysis of Number of Children, Stratified by Immigrant Status

\begin{tabular}{|c|c|c|c|c|}
\hline & Natives & Immigrants & $\begin{array}{c}\text { Immigrants, + } \\
\text { years in US }\end{array}$ & $\begin{array}{c}\text { Immigrants, }+ \\
\text { birthplace }\end{array}$ \\
\hline Age & $\begin{array}{c}0.2553 * * * \\
(0.0008)\end{array}$ & $\begin{array}{l}0.2484 * * * \\
(0.0024)\end{array}$ & $\begin{array}{c}0.2377 * * * \\
(0.0024)\end{array}$ & $\begin{array}{l}0.2367 * * * \\
(0.0024)\end{array}$ \\
\hline Age squared & $\begin{array}{c}-0.0036 * * * \\
(0.00001)\end{array}$ & $\begin{array}{c}-0.0031^{* * *} \\
(0.00003)\end{array}$ & $\begin{array}{c}-0.0031^{* * * *} \\
(0.00003)\end{array}$ & $\begin{array}{c}-0.0030 * * * \\
(0.00003)\end{array}$ \\
\hline Married & $\begin{array}{c}0.6890 * * * \\
(0.0027)\end{array}$ & $\begin{array}{c}0.8472 * * * \\
(0.0079)\end{array}$ & $\begin{array}{c}0.8655 * * * \\
(0.0079)\end{array}$ & $\begin{array}{c}0.8623 * * * \\
(0.0078)\end{array}$ \\
\hline High School Graduate & $\begin{array}{c}-0.2508 * * * \\
(0.0039)\end{array}$ & $\begin{array}{c}-0.4244 * * * \\
(0.0087)\end{array}$ & $\begin{array}{c}-0.4333^{* * *} \\
(0.0087)\end{array}$ & $\begin{array}{c}-0.4107 * * * \\
(0.0088)\end{array}$ \\
\hline College Graduate & $\begin{array}{c}-0.4426 * * * \\
(0.0046)\end{array}$ & $\begin{array}{c}-0.7248 * * * \\
(0.0113)\end{array}$ & $\begin{array}{c}-0.7096 * * * \\
(0.0113)\end{array}$ & $\begin{array}{c}-0.6731 * * * \\
0.0114\end{array}$ \\
\hline White & $\begin{array}{c}-0.0633^{* * *} \\
(0.0055)\end{array}$ & $\begin{array}{c}-0.0766^{* * *} \\
(0.0075)\end{array}$ & $\begin{array}{c}-0.0689 * * * \\
(0.0075)\end{array}$ & $\begin{array}{c}-0.0927 * * * \\
(0.0091)\end{array}$ \\
\hline Black & $\begin{array}{c}0.1954 * * * \\
(0.0064)\end{array}$ & $\begin{array}{c}0.2262 * * * \\
(0.0150)\end{array}$ & $\begin{array}{c}0.2174 * * * \\
(0.0149)\end{array}$ & $\begin{array}{c}0.0703 * * * \\
(0.0193)\end{array}$ \\
\hline Hispanic & $\begin{array}{c}0.1342 * * * \\
(0.0055)\end{array}$ & $\begin{array}{c}0.2262 * * * \\
(0.0082)\end{array}$ & $\begin{array}{c}0.22314 * * * \\
(0.0082)\end{array}$ & $\begin{array}{c}0.0971 * * * \\
(0.0173)\end{array}$ \\
\hline Household Income & $\begin{array}{c}-4.54 \mathrm{e}-07 * * * \\
(7.93 \mathrm{e}-09)\end{array}$ & $\begin{array}{c}-4.12 \mathrm{e}-07^{* * *} \\
(3.07 \mathrm{e}-08)\end{array}$ & $\begin{array}{c}-4.66 \mathrm{e}-07 * * * \\
(3.05 \mathrm{e}-08)\end{array}$ & $\begin{array}{c}-4.49 \mathrm{e}-07^{* * *} \\
(3.05 \mathrm{e}-08)\end{array}$ \\
\hline \multicolumn{5}{|c|}{ Years in USA (omitted category 0-5) } \\
\hline $6-10$ years & -- & -- & $\begin{array}{c}0.2231 * * * \\
(0.0108)\end{array}$ & $\begin{array}{c}0.2172 * * * \\
(0.0108)\end{array}$ \\
\hline 11-15 years & -- & -- & $\begin{array}{c}0.3576 * * * \\
(0.0113)\end{array}$ & $\begin{array}{c}0.3529 * * * \\
(0.0113)\end{array}$ \\
\hline $16-20$ years & -- & -- & $\begin{array}{c}0.4194 * * * \\
(0.0121)\end{array}$ & $\begin{array}{c}0.4138 * * * \\
(0.0121)\end{array}$ \\
\hline $21+$ years & -- & -- & $\begin{array}{c}0.3105 * * * \\
(0.0111)\end{array}$ & $\begin{array}{c}0.3057 * * * \\
(0.0111)\end{array}$ \\
\hline \multicolumn{5}{|c|}{ Place of Birth (other North America omitted) } \\
\hline $\begin{array}{l}\text { Central } \\
\text { America/Caribbean }\end{array}$ & -- & -- & -- & $\begin{array}{c}0.1804 * * * \\
(0.0279)\end{array}$ \\
\hline South America & -- & -- & -- & $\begin{array}{l}-0.0232 \\
(0.0292)\end{array}$ \\
\hline Europe & -- & -- & -- & $\begin{array}{c}0.0081 \\
(0.0238)\end{array}$ \\
\hline East Asia & -- & -- & -- & $\begin{array}{c}-0.1627 * * * \\
(0.0258)\end{array}$ \\
\hline South Asia & -- & & & $\begin{array}{c}0.0535 * * \\
(0.0249)\end{array}$ \\
\hline Rest of Asia & -- & -- & -- & $\begin{array}{c}0.4078 * * * \\
(0.0356)\end{array}$ \\
\hline Africa & -- & -- & -- & $0.1811 * * *$ \\
\hline
\end{tabular}




\begin{tabular}{l|cccc}
\hline \multirow{2}{*}{ Oceania } & & & & $(0.0323)$ \\
& -- & - & -- & $0.1613^{* * *}$ \\
& & & & 0.0491 \\
$\mathrm{~N}$ & & & & 107,063 \\
\hline
\end{tabular}

Notes: Regressions control for region of residence. 
Table 6: Synthetic Cohort Analysis of Number of Children

\begin{tabular}{l|cccc}
\hline & \multicolumn{2}{|c}{ Raw Differences } & \multicolumn{2}{c}{$\begin{array}{c}\text { Adjusted for all Control } \\
\text { Variables }\end{array}$} \\
& 1990 & 2000 & 1990 & 2000 \\
& & & & \\
Native & 0.793 & 1.342 & 1.005 & 1.554 \\
Immigrant & 0.861 & 1.696 & 0.861 & 1.696 \\
Immigrants, based on & & & & \\
year of arrival & & & & \\
$\quad$ Pre-1970 & & & 1.005 & 1.641 \\
1970-1974 & 1.098 & 1.580 & 1.019 & 1.693 \\
$1975-1979$ & 0.806 & 1.572 & 1.012 & 1.756 \\
$1980-1984$ & 1.017 & 1.705 & 0.916 & 1.755 \\
$1985-1989$ & 1.003 & 1.800 & 0.644 & 1.644 \\
\hline
\end{tabular}


Table 7: Odds Ratios from Cox Proportional Hazard Models of Mortality, among HRS Respondents Ages 51 and Older

\begin{tabular}{|c|c|c|c|c|c|c|c|c|c|c|c|c|}
\hline \multirow[b]{3}{*}{ Immigrant } & \multicolumn{6}{|c|}{ Men } & \multicolumn{6}{|c|}{ Women } \\
\hline & $(1)$ & & $(2)$ & & (3) & & (1) & & (2) & & (3) & \\
\hline & $\begin{array}{c}0.56 \\
(0.05)\end{array}$ & $* * *$ & $\begin{array}{l}0.65 \\
(0.1)\end{array}$ & $* * *$ & $\begin{array}{l}0.69 \\
(0.1)\end{array}$ & $* *$ & $\begin{array}{c}0.59 \\
(0.05)\end{array}$ & $* * *$ & $\begin{array}{c}0.64 \\
(0.09)\end{array}$ & $* * *$ & $\begin{array}{l}0.66 \\
(0.1)\end{array}$ & $* * *$ \\
\hline Age & $\begin{array}{c}1.12 \\
(0.02)\end{array}$ & $* * *$ & $\begin{array}{c}1.12 \\
(0.02)\end{array}$ & $* * *$ & $\begin{array}{c}1.13 \\
(0.02)\end{array}$ & $* * *$ & $\begin{array}{c}1.16 \\
(0.02)\end{array}$ & $* * *$ & $\begin{array}{c}1.16 \\
(0.02)\end{array}$ & $* * *$ & $\begin{array}{c}1.17 \\
(0.02)\end{array}$ & $* * *$ \\
\hline Age squared & $\begin{array}{c}1.00 \\
(0.0001)\end{array}$ & & $\begin{array}{c}1.00 \\
(0.0001)\end{array}$ & & $\begin{array}{c}1.00 \\
(0.0001)\end{array}$ & $*$ & $\begin{array}{c}1.00 \\
(0.0001)\end{array}$ & & $\begin{array}{c}1.00 \\
(0.0001)\end{array}$ & $* * *$ & $\begin{array}{c}1.00 \\
(0.0001)\end{array}$ & $* * *$ \\
\hline Age when immigrated & $\begin{array}{l}-- \\
--\end{array}$ & & $\begin{array}{c}1.00 \\
(0.004)\end{array}$ & & $\begin{array}{c}0.99 \\
(0.004)\end{array}$ & $*$ & -- & & $\begin{array}{c}1.00 \\
(0.004)\end{array}$ & & $\begin{array}{c}1.00 \\
(0.004)\end{array}$ & \\
\hline Black & $\begin{array}{c}1.20 \\
(0.06)\end{array}$ & $* * *$ & $\begin{array}{c}1.20 \\
(0.06)\end{array}$ & $* * *$ & $\begin{array}{c}1.14 \\
(0.06)\end{array}$ & $* * *$ & $\begin{array}{c}1.20 \\
(0.06)\end{array}$ & $* * *$ & $\begin{array}{c}1.20 \\
(0.06)\end{array}$ & $* * *$ & $\begin{array}{c}1.13 \\
(0.05)\end{array}$ & $* *$ \\
\hline Other (non-white) race & $\begin{array}{c}1.20 \\
(0.13)\end{array}$ & $*$ & $\begin{array}{c}1.20 \\
(0.13)\end{array}$ & * & $\begin{array}{c}1.16 \\
(0.13)\end{array}$ & & $\begin{array}{c}1.33 \\
(0.15)\end{array}$ & $* *$ & $\begin{array}{c}1.33 \\
(0.15)\end{array}$ & $* *$ & $\begin{array}{c}1.28 \\
(0.15)\end{array}$ & $* *$ \\
\hline Hispanic & $\begin{array}{c}0.95 \\
(0.08)\end{array}$ & & $\begin{array}{c}0.96 \\
(0.08)\end{array}$ & & $\begin{array}{c}0.91 \\
(0.08)\end{array}$ & & $\begin{array}{c}0.82 \\
(0.08)\end{array}$ & $* *$ & $\begin{array}{c}0.82 \\
(0.08)\end{array}$ & $* *$ & $\begin{array}{c}0.80 \\
(0.08)\end{array}$ & $* *$ \\
\hline Years of education & $\begin{array}{c}0.97 \\
(0.005)\end{array}$ & $* * *$ & $\begin{array}{c}0.97 \\
(0.005)\end{array}$ & $* * *$ & $\begin{array}{c}0.98 \\
(0.01)\end{array}$ & $* * *$ & $\begin{array}{c}0.96 \\
(0.01)\end{array}$ & $* * *$ & $\begin{array}{c}0.96 \\
(0.01)\end{array}$ & $* * *$ & $\begin{array}{c}0.98 \\
(0.01)\end{array}$ & $* * *$ \\
\hline Ln household income & -- & & -- & & $\begin{array}{c}0.83 \\
(0.02)\end{array}$ & $* * *$ & -- & & -- & & $\begin{array}{c}0.88 \\
(0.02)\end{array}$ & $* * *$ \\
\hline Private or Medicare Health Insurance & $\begin{array}{l}-- \\
--\end{array}$ & & -- & & $\begin{array}{c}0.75 \\
(0.05)\end{array}$ & $* * *$ & -- & & -- & & $\begin{array}{c}0.64 \\
(0.04)\end{array}$ & $* * *$ \\
\hline $\mathrm{N}$ & 10,854 & & 10,854 & & 10,854 & & 12,791 & & 12,791 & & 12,791 & \\
\hline N Failures & 3,306 & & 3,306 & & 3,306 & & 3,329 & & 3,329 & & 3,329 & \\
\hline
\end{tabular}

Notes: Standard errors of the odds ratios in parentheses. Respondents with missing values are dropped.

*** denotes statistical significance at the $1 \%$ level,, ** at the $5 \%$ level, and * at the $10 \%$ level.

All right hand side variables are as reported at the respondent's first HRS interview. Time is measured as months since first interviewed. 
Table 8: Regressions of Self Reported Probabilities of Life Expectancy

\begin{tabular}{|c|c|c|c|c|c|c|c|c|c|c|c|c|}
\hline \multirow[b]{3}{*}{ Immigrant } & \multicolumn{4}{|c|}{ Live to Age 75} & \multicolumn{4}{|c|}{ Live to Age 85} & \multicolumn{4}{|c|}{ Live to be $80 / 85 / 90 / 100$} \\
\hline & \multicolumn{2}{|l|}{ Men } & \multicolumn{2}{|c|}{ Women } & \multicolumn{2}{|l|}{ Men } & \multicolumn{2}{|c|}{ Women } & \multicolumn{2}{|l|}{ Men } & \multicolumn{2}{|l|}{ Women } \\
\hline & $\begin{array}{c}1.21 \\
(2.21)\end{array}$ & & $\begin{array}{c}1.99 \\
(2)\end{array}$ & & $\begin{array}{c}5.16 \\
(3.22)\end{array}$ & & $\begin{array}{l}1.54 \\
(2.9)\end{array}$ & & $\begin{array}{c}0.84 \\
(2.38)\end{array}$ & & $\begin{array}{l}-0.47 \\
(2.03)\end{array}$ & \\
\hline Age & $\begin{array}{c}0.53 \\
(0.05)\end{array}$ & $* * *$ & $\begin{array}{c}0.20 \\
(0.05)\end{array}$ & $* * *$ & $\begin{array}{c}0.70 \\
(0.07)\end{array}$ & $* * *$ & $\begin{array}{c}0.23 \\
(0.07)\end{array}$ & $* * *$ & $\begin{array}{l}-0.22 \\
(0.04)\end{array}$ & $* * *$ & $\begin{array}{l}-0.48 \\
(0.03)\end{array}$ & $* * *$ \\
\hline Age when immigrated & $\begin{array}{l}-0.03 \\
(0.07)\end{array}$ & & $\begin{array}{l}-0.11 \\
(0.07)\end{array}$ & & $\begin{array}{c}-0.13 \\
(0.1)\end{array}$ & & $\begin{array}{l}-0.09 \\
(0.09)\end{array}$ & & $\begin{array}{c}0.06 \\
(0.07)\end{array}$ & & $\begin{array}{l}-0.01 \\
(0.07)\end{array}$ & \\
\hline Health=very good & $\begin{array}{l}-6.70 \\
(0.54)\end{array}$ & $* * *$ & $\begin{array}{l}-6.59 \\
(0.45)\end{array}$ & $* * *$ & $\begin{array}{l}-9.80 \\
(0.79)\end{array}$ & $* * *$ & $\begin{array}{l}-9.28 \\
(0.73)\end{array}$ & $* * *$ & $\begin{array}{l}-8.48 \\
(0.78)\end{array}$ & $* * *$ & $\begin{array}{l}-9.45 \\
(0.65)\end{array}$ & $* * *$ \\
\hline Health=good & $\begin{array}{c}-14.53 \\
(0.63)\end{array}$ & $* * *$ & $\begin{array}{c}-13.09 \\
(0.55)\end{array}$ & $* * *$ & $\begin{array}{c}-17.15 \\
(0.84)\end{array}$ & $* * *$ & $\begin{array}{c}-15.77 \\
(0.82)\end{array}$ & $* * *$ & $\begin{array}{c}-17.51 \\
(0.83)\end{array}$ & $* * *$ & $\begin{array}{c}-18.03 \\
(0.71)\end{array}$ & $* * *$ \\
\hline Health=fair & $\begin{array}{c}-25.56 \\
(0.86)\end{array}$ & $* * *$ & $\begin{array}{c}-22.42 \\
(0.73)\end{array}$ & $* * *$ & $\begin{array}{c}-27.26 \\
(1.01)\end{array}$ & $* * *$ & $\begin{array}{c}-25.39 \\
(1)\end{array}$ & $* * *$ & $\begin{array}{c}-27.35 \\
(0.98)\end{array}$ & $* * *$ & $\begin{array}{c}-26.11 \\
(0.83)\end{array}$ & $* * *$ \\
\hline Health=poor & $\begin{array}{c}-39.30 \\
(1.2)\end{array}$ & $* * *$ & $\begin{array}{c}-35.30 \\
(1.07)\end{array}$ & $* * *$ & $\begin{array}{c}-37.88 \\
(1.25)\end{array}$ & $* * *$ & $\begin{array}{c}-34.83 \\
(1.27)\end{array}$ & $* * *$ & $\begin{array}{c}-37.23 \\
(1.27)\end{array}$ & $* * *$ & $\begin{array}{c}-36.23 \\
(1.04)\end{array}$ & $* * *$ \\
\hline Black & $\begin{array}{c}8.72 \\
(0.85)\end{array}$ & $* * *$ & $\begin{array}{c}4.90 \\
(0.71)\end{array}$ & $* * *$ & $\begin{array}{l}14.78 \\
(1.04)\end{array}$ & $* * *$ & $\begin{array}{l}11.62 \\
(0.95)\end{array}$ & $* * *$ & $\begin{array}{l}12.74 \\
(1.02)\end{array}$ & $* * *$ & $\begin{array}{c}9.95 \\
(0.81)\end{array}$ & *** \\
\hline Other (non-white) race & $\begin{array}{c}0.36 \\
(1.49)\end{array}$ & & $\begin{array}{c}1.78 \\
(1.34)\end{array}$ & & $\begin{array}{c}2.40 \\
(1.95)\end{array}$ & & $\begin{array}{c}6.13 \\
(1.75)\end{array}$ & *** & $\begin{array}{c}1.13 \\
(1.75)\end{array}$ & & $\begin{array}{c}2.55 \\
(1.51)\end{array}$ & $*$ \\
\hline Hispanic & $\begin{array}{c}2.00 \\
(1.19)\end{array}$ & * & $\begin{array}{l}-4.34 \\
(1.08)\end{array}$ & $* * *$ & $\begin{array}{c}3.13 \\
(1.43)\end{array}$ & $* *$ & $\begin{array}{l}-0.42 \\
(1.46)\end{array}$ & & $\begin{array}{c}2.42 \\
(1.39)\end{array}$ & * & $\begin{array}{l}-1.36 \\
(1.19)\end{array}$ & \\
\hline Years of education & $\begin{array}{l}0.41 \\
(0.1)\end{array}$ & $* * *$ & $\begin{array}{l}0.87 \\
(0.1)\end{array}$ & $* * *$ & $\begin{array}{c}0.13 \\
(0.11)\end{array}$ & & $\begin{array}{c}0.94 \\
(0.13)\end{array}$ & $* * *$ & $\begin{array}{c}0.05 \\
(0.11)\end{array}$ & & $\begin{array}{l}0.57 \\
(0.1)\end{array}$ & $* * *$ \\
\hline Married & $\begin{array}{c}1.39 \\
(0.69)\end{array}$ & $* *$ & $\begin{array}{l}-1.43 \\
(0.53)\end{array}$ & $* * *$ & $\begin{array}{c}0.89 \\
(0.89)\end{array}$ & & $\begin{array}{l}-1.09 \\
(0.73)\end{array}$ & & $\begin{array}{c}1.16 \\
(0.72)\end{array}$ & & $\begin{array}{c}0.10 \\
(0.55)\end{array}$ & \\
\hline
\end{tabular}




\begin{tabular}{|c|c|c|c|c|c|c|c|c|}
\hline Ln household income & $\begin{array}{c}1.38 \\
(0.27)\end{array}$ & $\begin{array}{c}1.48 \\
(0.22)\end{array}$ & $\begin{array}{c}0.21 \\
(0.37)\end{array}$ & $\begin{array}{c}0.68 \\
(0.31)\end{array}$ & $* *$ & $\begin{array}{c}0.86 \\
(0.33)\end{array}$ & ** & $\begin{array}{c}1.06 \\
(0.27)\end{array}$ \\
\hline Private or Medicare Health Insurance & $\begin{array}{l}-0.29 \\
(0.66)\end{array}$ & $\begin{array}{l}-0.20 \\
(0.55)\end{array}$ & $\begin{array}{l}-0.55 \\
(0.83)\end{array}$ & $\begin{array}{l}-2.30 \\
(0.77)\end{array}$ & $* * *$ & $\begin{array}{c}4.65 \\
(0.78)\end{array}$ & $* * *$ & $\begin{array}{c}4.31 \\
(0.63)\end{array}$ \\
\hline R-squared & 0.16 & 0.16 & 0.13 & 0.12 & & 0.13 & & 0.15 \\
\hline Number observations & 23,491 & 31,652 & 16,640 & 19,402 & & 18,171 & & 25,984 \\
\hline Age of Sample & $51-65$ & $51-65$ & $51-75$ & $51-75$ & & $51-90$ & & $51-90$ \\
\hline Years Included & 1992-2004 & 1992-2004 & 1992-1998 & 1992-1998 & & $2000-2004$ & & 2000-2004 \\
\hline
\end{tabular}

Notes: Standard errors, clustered at the respondent level, in parentheses.

*** denotes statistical significance at the $1 \%$ level,, ** at the $5 \%$ level, and * at the $10 \%$ level.

Respondents with missing values for variables are excluded. 
Appendix Table 1: Summary Statistics, American Community Survey

\begin{tabular}{l|ccc}
\hline & Full Sample & Native-born & Immigrant \\
\hline & & & \\
Fertility last year & 0.055 & 0.052 & 0.075 \\
Immigrant & 0.122 & -- & -- \\
Age & 33.793 & 33.721 & 34.31 \\
Married & 0.534 & 0.520 & 0.632 \\
High School Graduate & 0.585 & 0.600 & 0.483 \\
College Graduate & 0.254 & 0.250 & 0.282 \\
White & 0.787 & 0.835 & 0.449 \\
Black & 0.100 & 0.104 & 0.071 \\
Hispanic & 0.095 & 0.056 & 0.375 \\
& & & \\
$\mathrm{~N}$ & 570,284 & 500,596 & 69,688 \\
\hline
\end{tabular}


Appendix Table 2: Summary Statistics, Decennial Census

\begin{tabular}{l|ccc}
\hline & Full Sample & Native-born & Immigrant \\
\hline A. 2000 & & & \\
Number of children & 0.962 & 0.919 & 1.233 \\
& $(1.196)$ & $(1.160)$ & $(1.373)$ \\
Immigrant & 0.135 & - & -- \\
Age & 34.818 & 34.811 & 34.865 \\
& $(11.303)$ & $(11.436)$ & $(10.407)$ \\
Married & 0.535 & 0.522 & 0.620 \\
High School Graduate & 0.607 & 0.628 & 0.480 \\
College Graduate & 0.214 & 0.214 & 0.215 \\
White & 0.751 & 0.805 & 0.402 \\
Black & 0.121 & 0.129 & 0.069 \\
Hispanic & 0.116 & 0.064 & 0.452 \\
& & & \\
N & 792,611 & 685,548 & 107,063 \\
& & & \\
B. 1990 & & & 1.235 \\
Number of children & 1.022 & 1.000 & $(1.399)$ \\
Immigrant & $(1.208)$ & $(1.184)$ & -- \\
Age & 0.093 & -- & 34.001 \\
& 33.401 & 33.340 & $(10.497)$ \\
Married & $(10.759)$ & $(10.784)$ & 0.623 \\
High School Graduate & 0.563 & 0.557 & 0.494 \\
College Graduate & 0.631 & 0.645 & 0.182 \\
White & 0.175 & 0.174 & 0.482 \\
Black & 0.813 & 0.847 & 0.068 \\
Hispanic & 0.111 & 0.116 & 0.395 \\
& 0.079 & 0.047 & 65,222 \\
N & & & \\
\hline
\end{tabular}


Appendix Table 3

Summary Statistics for HRS Samples Used in Hazard Models

\begin{tabular}{|c|c|c|c|c|c|c|c|c|}
\hline & \multicolumn{4}{|c|}{ Men } & \multicolumn{4}{|c|}{ Women } \\
\hline & \multicolumn{2}{|c|}{ Non-immigrants } & \multicolumn{2}{|c|}{ Immigrants } & \multicolumn{2}{|c|}{ Non-immigrants } & \multicolumn{2}{|c|}{ Immigrants } \\
\hline & $\underline{\text { Mean }}$ & $\underline{\text { Std. Dev }}$ & $\underline{\text { Mean }}$ & $\underline{\text { Std. Dev }}$ & $\underline{\text { Mean }}$ & $\underline{\text { Std. Dev }}$ & $\underline{\text { Mean }}$ & $\underline{\text { Std. Dev }}$ \\
\hline Age & 63.79 & 10.17 & 62.02 & 9.54 & 65.63 & 11.03 & 63.10 & 10.53 \\
\hline Hispanic & 0.04 & 0.20 & 0.45 & 0.50 & 0.04 & 0.19 & 0.45 & 0.50 \\
\hline Other (non-white) race & 0.02 & 0.15 & 0.18 & 0.38 & 0.02 & 0.14 & 0.16 & 0.37 \\
\hline Household income & 49,812 & 56,666 & 56,566 & 282,051 & 38,011 & 57,484 & 38,525 & 52,132 \\
\hline Private or Medicare Health Insurance & 0.88 & 0.33 & 0.73 & 0.45 & 0.88 & 0.33 & 0.74 & 0.44 \\
\hline \multicolumn{9}{|l|}{ Health Insurance } \\
\hline None & 11.59 & & 24.91 & & 11.07 & & 24.30 & \\
\hline Private & 74.05 & & 54.15 & & 69.30 & & 51.21 & \\
\hline
\end{tabular}


Appendix Table 4

Summary Statistics for HRS Samples Used in Subjective Survival Probabilities

\begin{tabular}{|c|c|c|c|c|c|c|c|c|}
\hline & \multicolumn{4}{|c|}{ Men } & \multicolumn{4}{|c|}{ Women } \\
\hline & \multicolumn{2}{|c|}{ Non-immigrants } & \multicolumn{2}{|c|}{ Immigrants } & \multicolumn{2}{|c|}{ Non-immigrants } & \multicolumn{2}{|c|}{ Immigrants } \\
\hline & Mean & $\underline{\text { Std. Dev }}$ & Mean & $\underline{\text { Std. Dev }}$ & Mean & $\underline{\text { Std. Dev }}$ & Mean & Std. Dev \\
\hline Subjective probability live until 75 & 63.29 & 29.49 & 62.65 & 30.07 & 66.77 & 28.59 & 58.85 & 33.03 \\
\hline Subjective probability live until 85 & 40.44 & 31.71 & 42.37 & 32.35 & 46.31 & 32.12 & 40.10 & 33.50 \\
\hline Subjective probability live 10 years & 46.83 & 31.74 & 48.23 & 33.31 & 50.11 & 32.21 & 45.70 & 34.29 \\
\hline Age & 63.61 & 8.80 & 63.04 & 9.04 & 62.07 & 10.17 & 60.77 & 10.01 \\
\hline Black & 0.12 & 0.33 & 0.09 & 0.28 & 0.15 & 0.36 & 0.10 & 0.30 \\
\hline Hispanic & 0.04 & 0.20 & 0.45 & 0.50 & 0.04 & 0.20 & 0.46 & 0.50 \\
\hline Other (non-white) race & 0.02 & 0.14 & 0.18 & 0.39 & 0.02 & 0.15 & 0.18 & 0.39 \\
\hline Age when immigrated & & & 29.36 & 13.82 & & & 27.72 & 12.55 \\
\hline Years of education & 12.68 & 3.06 & 10.86 & 5.00 & 12.46 & 2.58 & 10.41 & 4.57 \\
\hline Married & 0.79 & 0.41 & 0.82 & 0.39 & 0.63 & 0.48 & 0.65 & 0.48 \\
\hline Household income & 62,385 & 94,692 & 54,471 & 78,993 & 51,079 & 73,097 & 47,047 & 141,206 \\
\hline Private or Medicare Health Insurance & 0.91 & 0.29 & 0.79 & 0.41 & 0.88 & 0.32 & 0.75 & 0.43 \\
\hline \multicolumn{9}{|l|}{ Health Insurance } \\
\hline None & 7.84 & & 18.06 & & 9.14 & & 19.82 & \\
\hline Private & 63.85 & & 50.46 & & 60.91 & & 49.21 & \\
\hline Medicare (but no private) & 26.94 & & 28.54 & & 27.38 & & 25.47 & \\
\hline Medicaid only & 1.37 & & 2.95 & & 2.57 & & 5.50 & \\
\hline \multicolumn{9}{|l|}{ Self Rated Health } \\
\hline Excellent & 16.30 & & 16.49 & & 15.70 & & 14.23 & \\
\hline Very Good & 30.15 & & 23.12 & & 31.33 & & 19.68 & \\
\hline Good & 30.53 & & 32.49 & & 29.42 & & 30.52 & \\
\hline Fair & 15.99 & & 21.05 & & 16.46 & & 24.15 & \\
\hline Poor & 7.02 & & 6.85 & & 7.09 & & 11.42 & \\
\hline $\mathrm{N}$ & 30,923 & & 2,614 & & 43,147 & & 3,985 & \\
\hline
\end{tabular}


Figure 1: One-year Mortality Rates in 2001, All Men

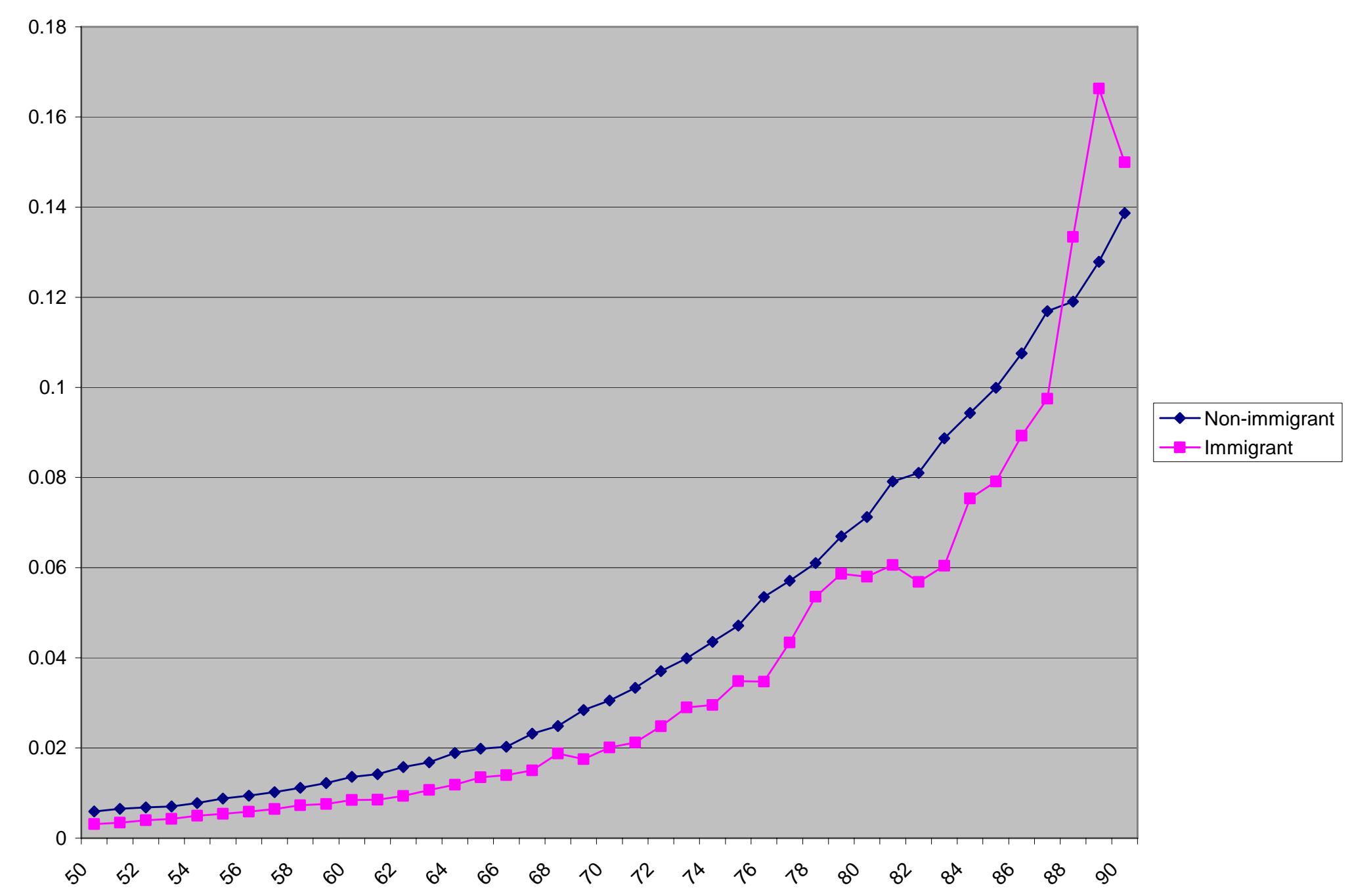

Notes: Numerators calculated from Vital Statistics Detail Mortality Data. Denominators calculated from Decennial Census IPUMS 
Figure 2: One-year Mortality Rates in 2001, All Women

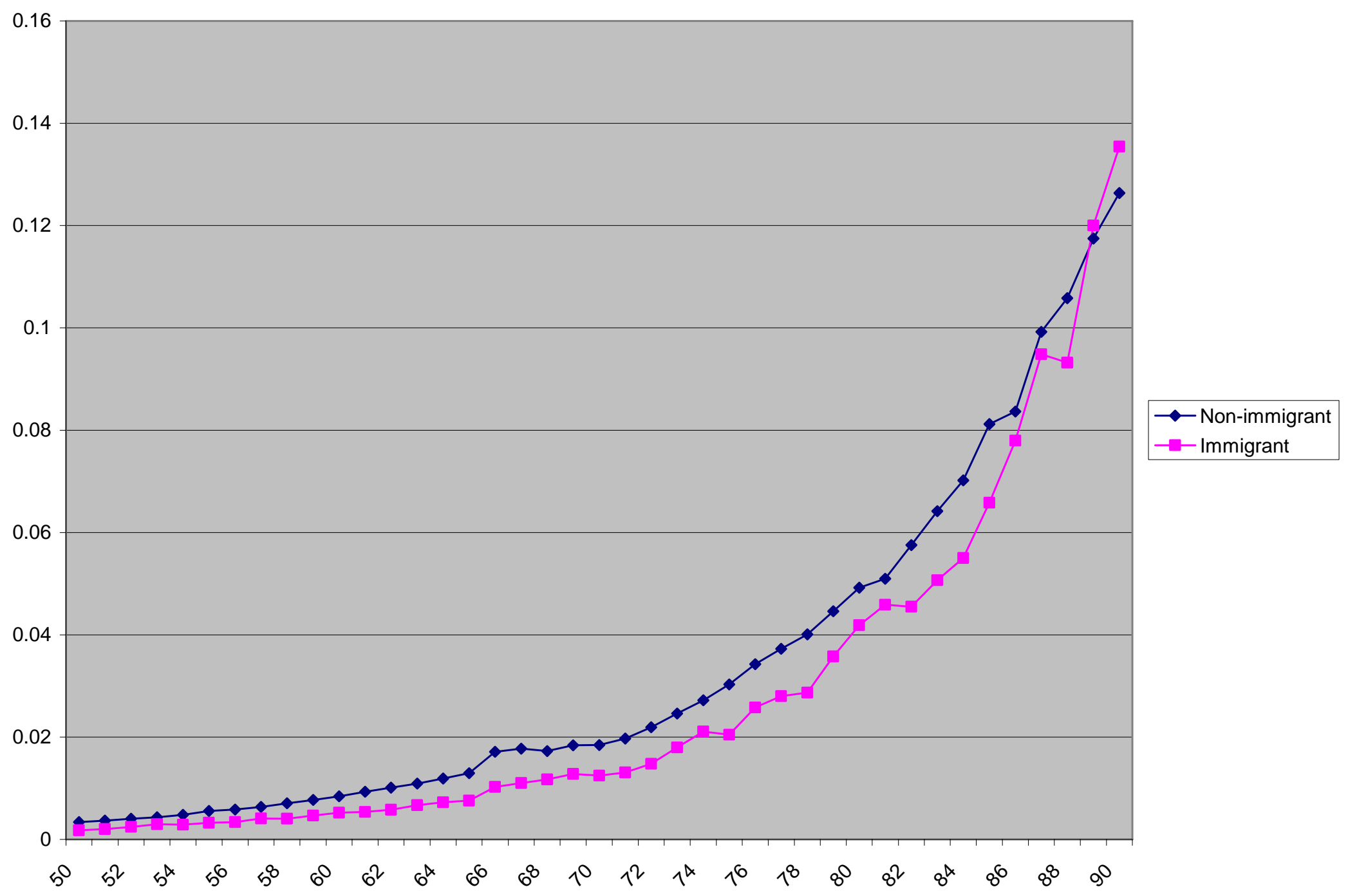

Notes: Numerators calculated from Vital Statistics Detail Mortality Data. Denominators calculated from Decennial Census IPUMS 
Figure 3a: One-year Mortality Rates in 2001, White Men

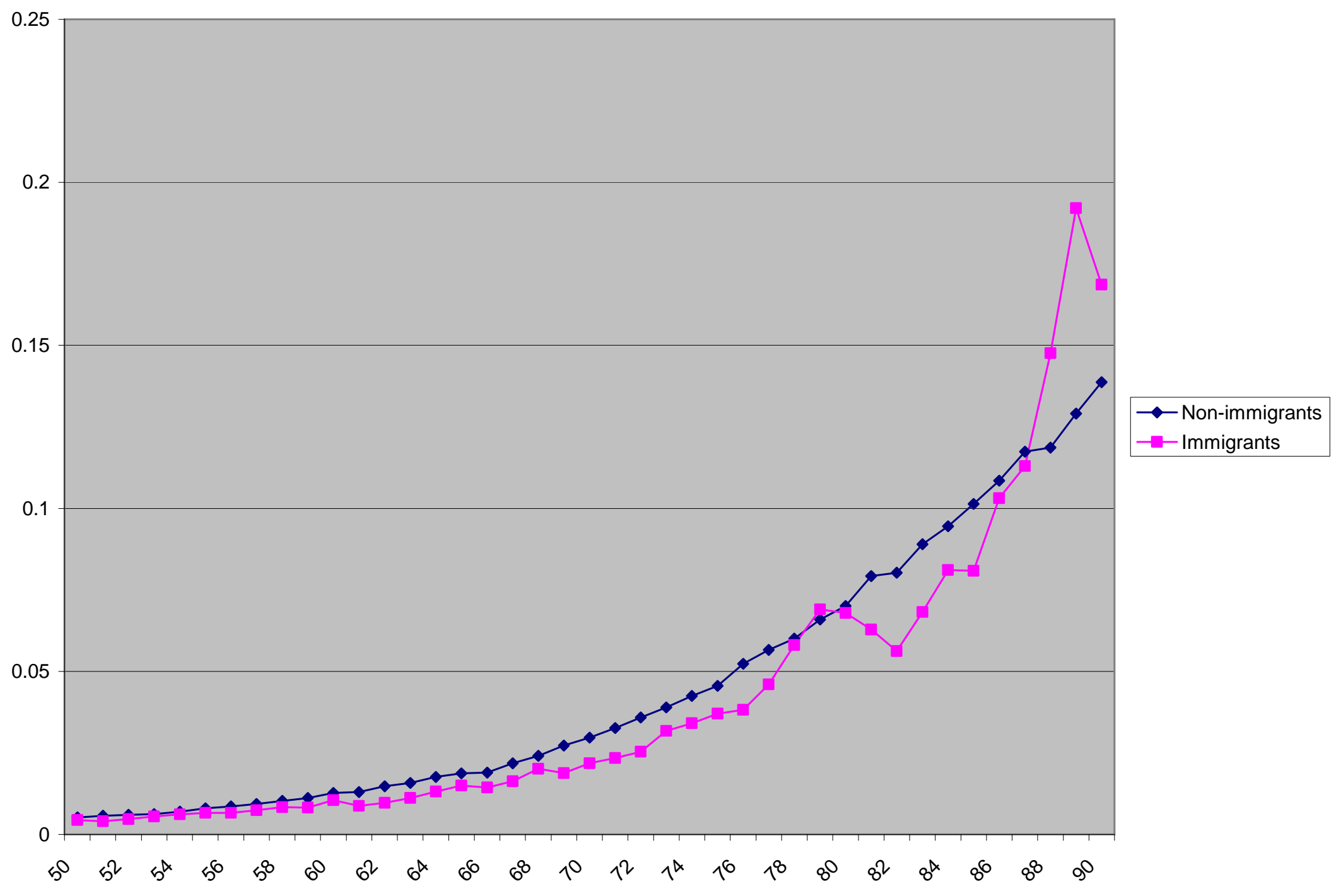


Notes: Numerators calculated from Vital Statistics Detail Mortality Data. Denominators calculated from Decennial Census IPUMS 
Figure 3b: One-year Mortality Rates in 2001, White Women

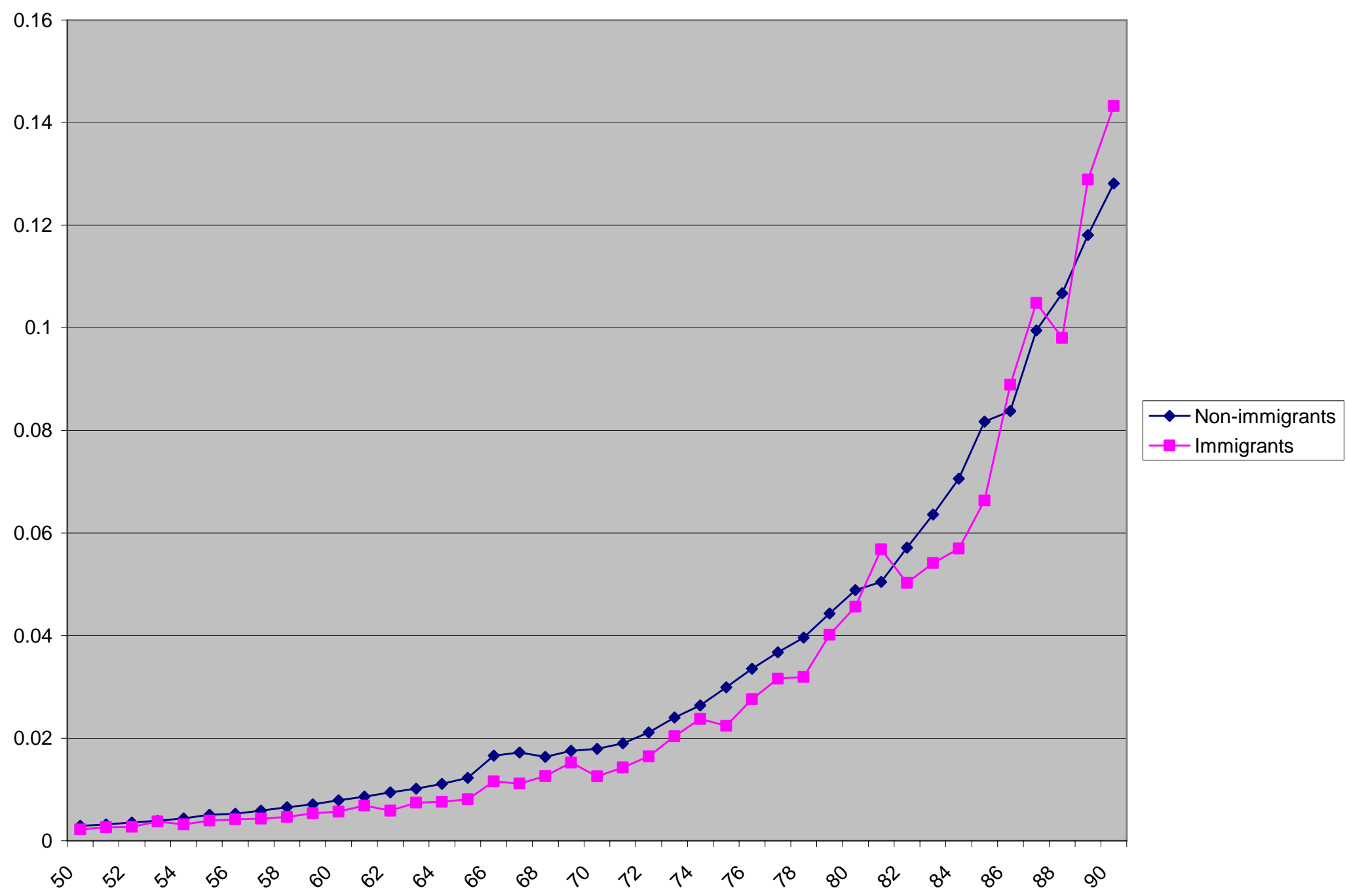

Notes: Numerators calculated from Vital Statistics Detail Mortality Data. Denominators calculated from Decennial Census IPUMS 
Figure 4a: One-year Mortality Rates in 2001, Black Men

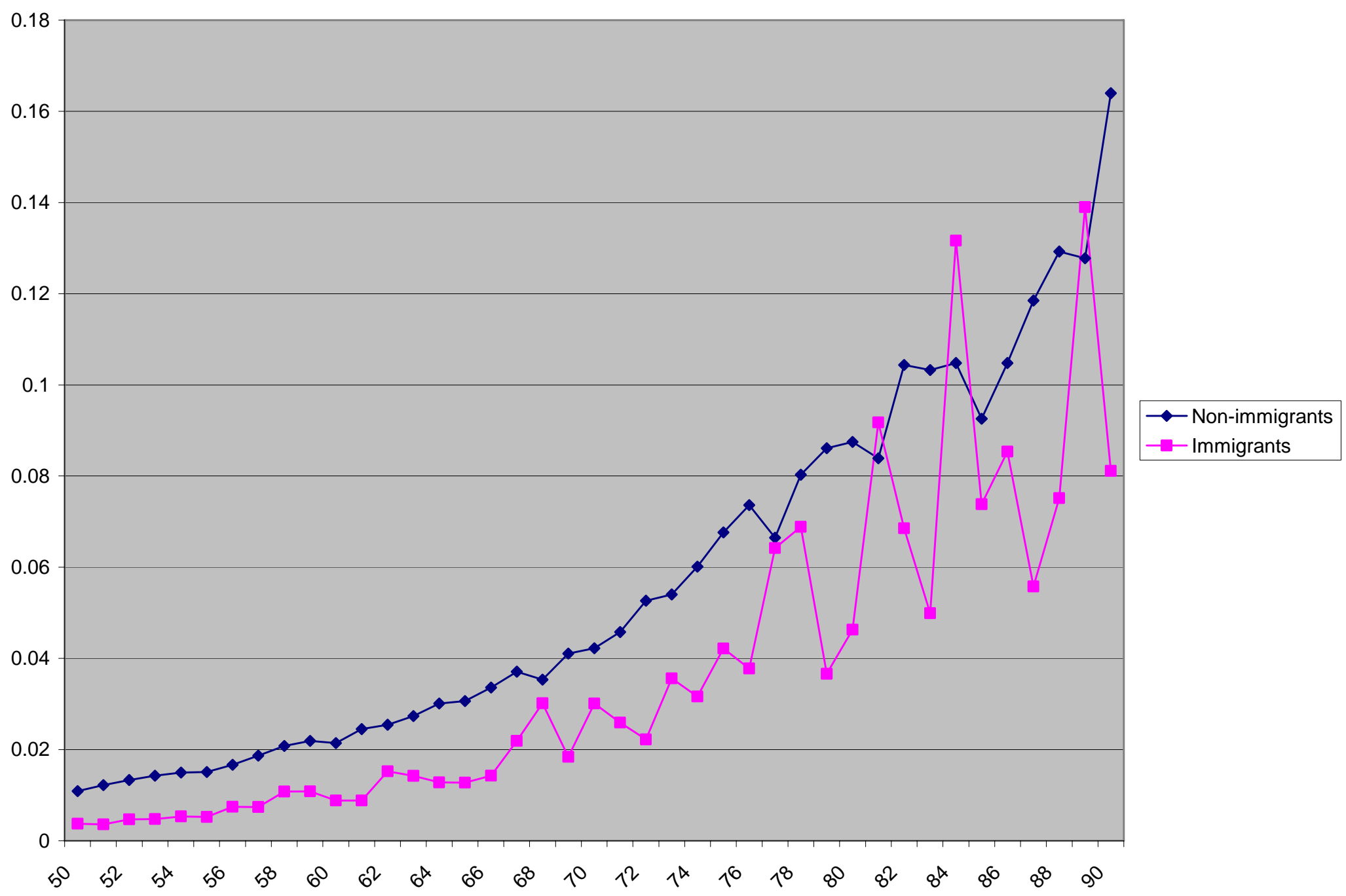

Notes: Numerators calculated from Vital Statistics Detail Mortality Data. Denominators calculated from Decennial Census IPUMS 
Figure 4b: One-year Mortality Rates in 2001, Black Women

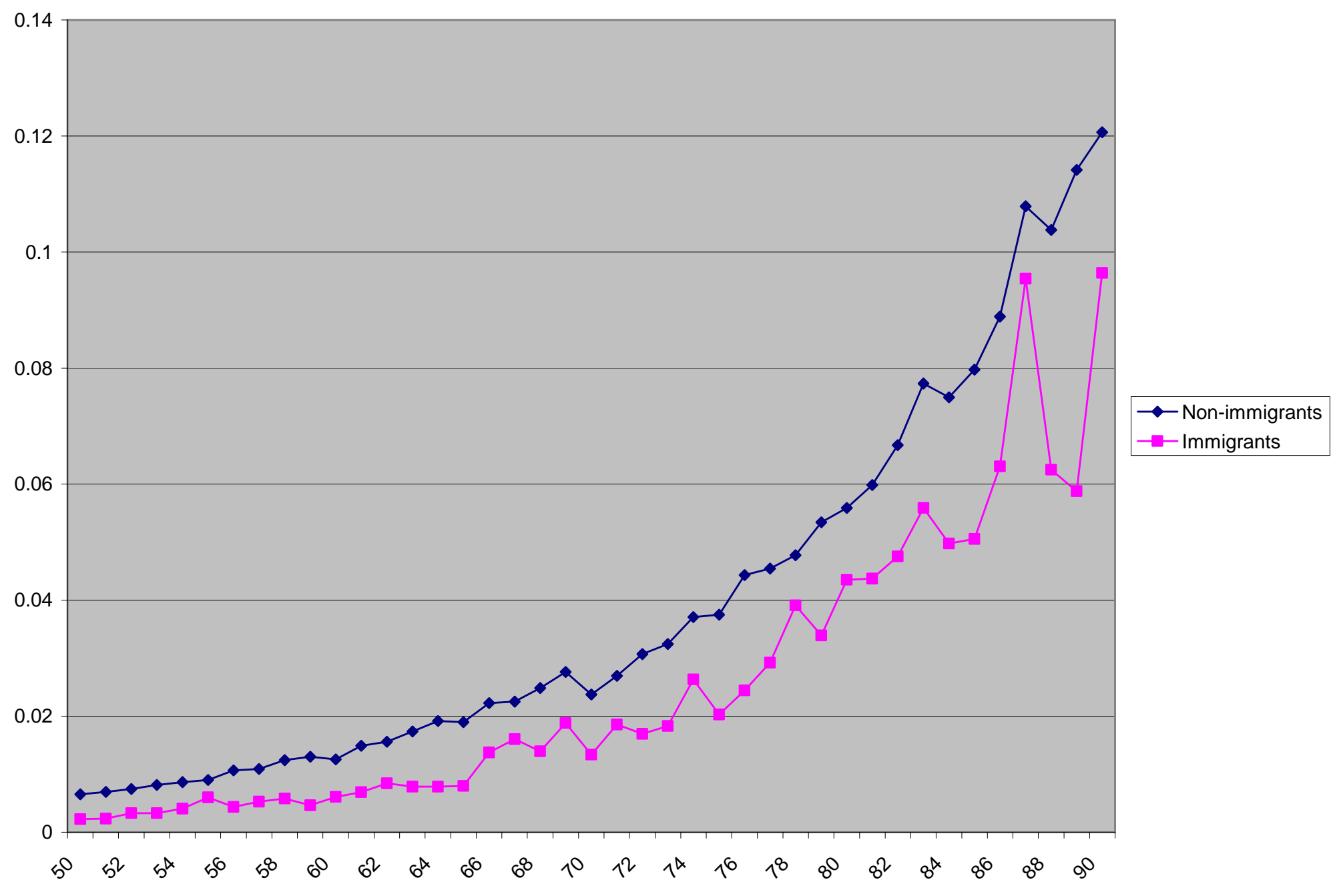

Notes: Numerators calculated from Vital Statistics Detail Mortality Data. Denominators calculated from Decennial Census IPUMS 
Figure 5a: One-year Mortality Rates in 2001, Hispanic Men

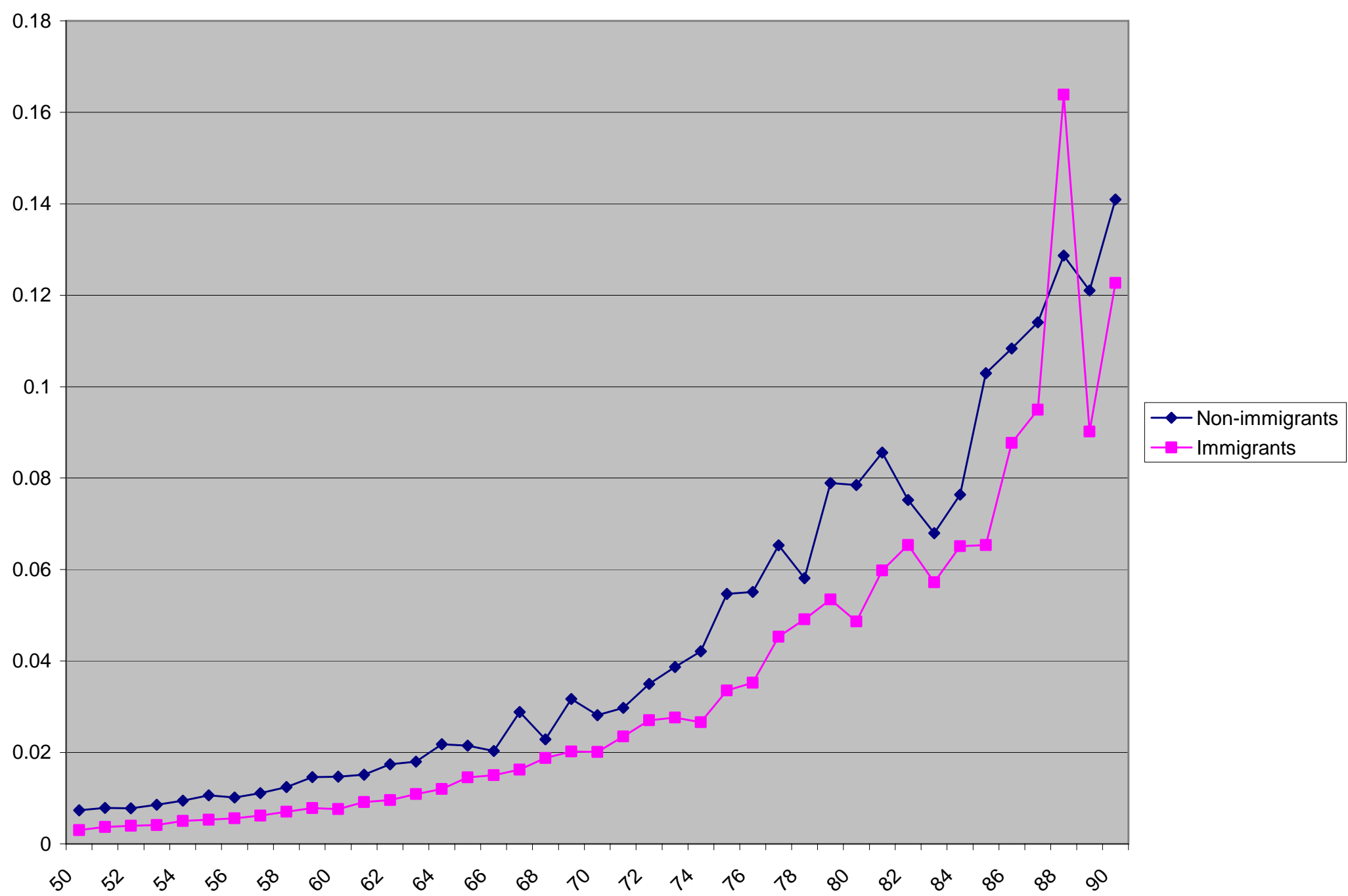

Notes: Numerators calculated from Vital Statistics Detail Mortality Data. Denominators calculated from Decennial Census IPUMS 
Figure 5b: One-year Mortality Rates in 2001, Hispanic Women

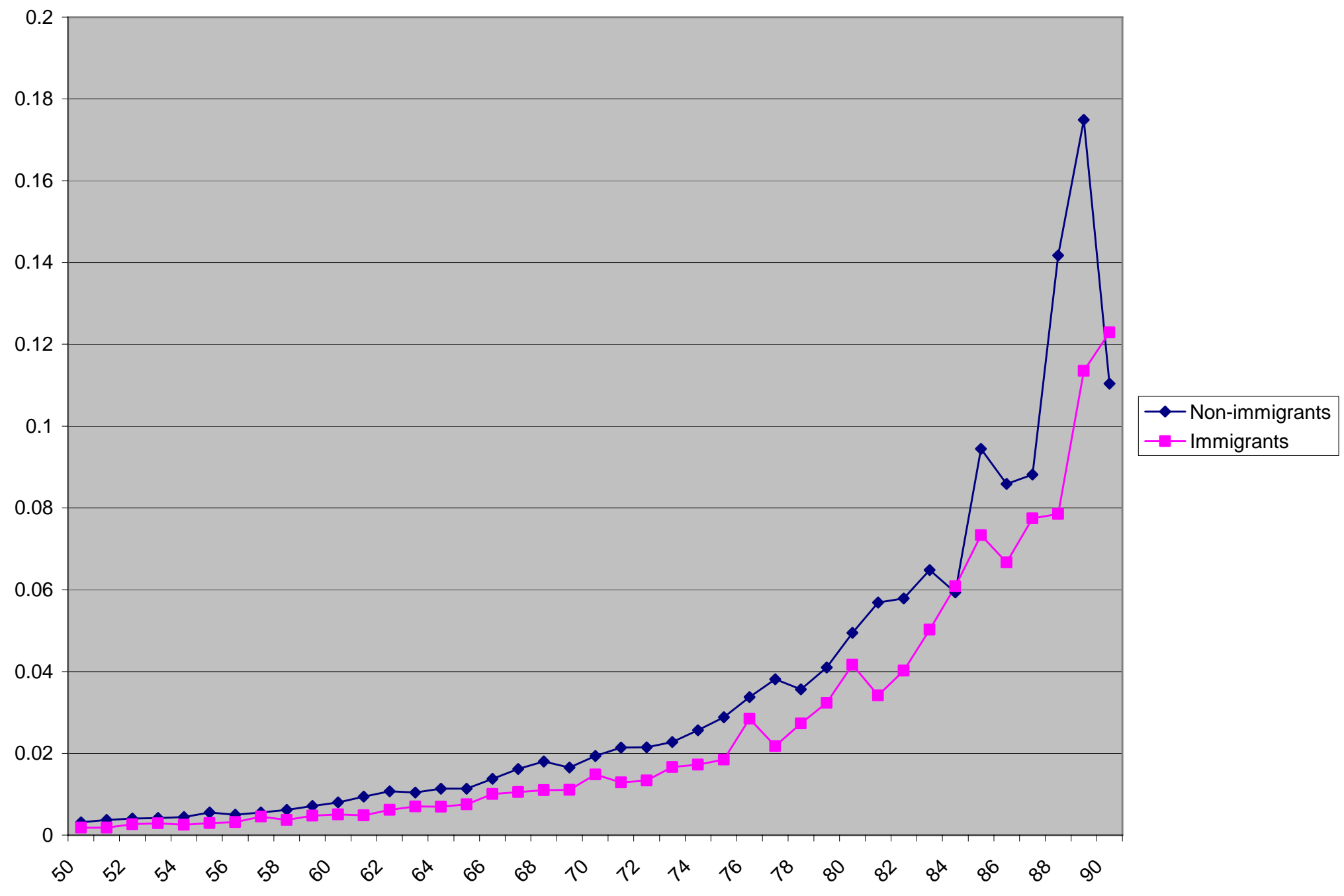

Notes: Numerators calculated from Vital Statistics Detail Mortality Data. Denominators calculated from Decennial Census IPUMS 
Figure 6a: One-year Mortality Rates in 2001, White vs. Hispanic Men, Non-Immigrants

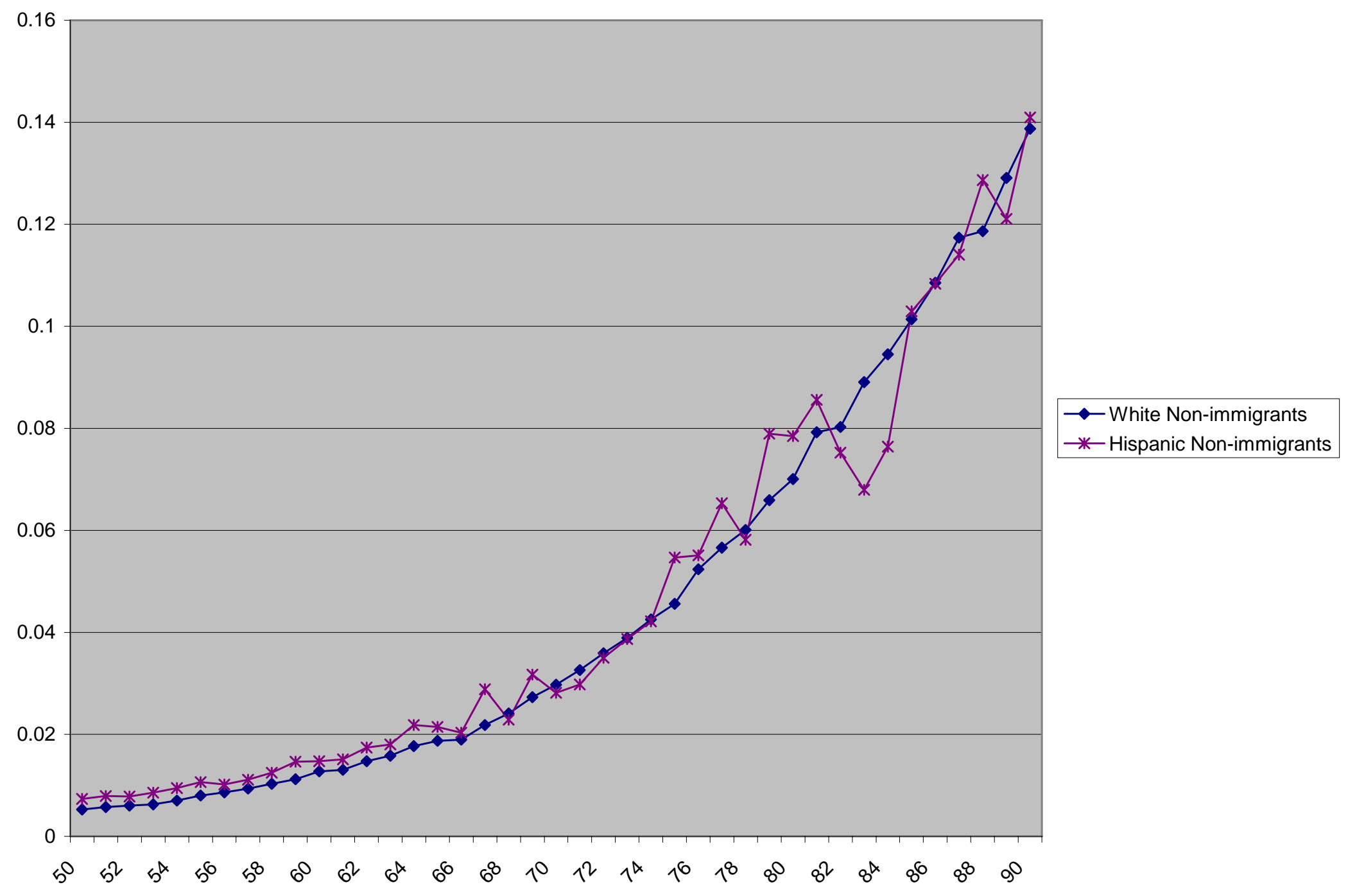

Notes: Numerators calculated from Vital Statistics Detail Mortality Data. Denominators calculated from Decennial Census IPUMS 
Figure 6a: One-year Mortality Rates in 2001, White vs. Hispanic Women, Non-Immigrants

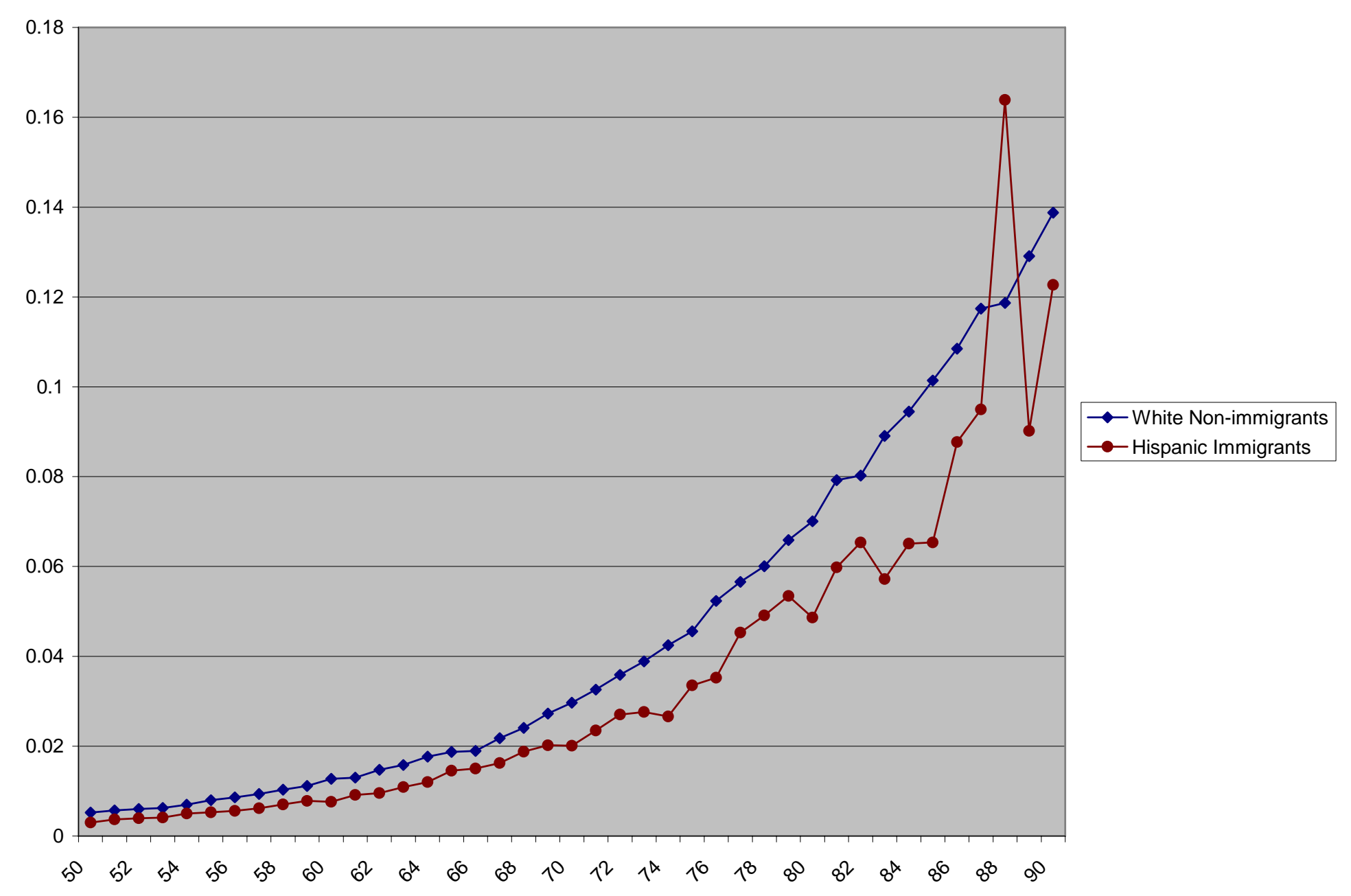

Notes: Numerators calculated from Vital Statistics Detail Mortality Data. Denominators calculated from Decennial Census IPUMS 